\title{
Masking the Focus on English Learners: The Consequences of California's Accountability System Dashboard Results on Year 4 Local Control and Accountability Plans (LCAPs)
}

Magaly Lavadenz Ph.D., Professor Department of Educational Leadership Director, Center for Equity for English Learners Loyola Marymount University, magaly.lavadenz@Imu.edu

Elvira G. Armas Ed.D., Associate Director

Center for Equity for English Learners Loyola Marymount University, Elvira.Armas@Imu.edu

Sylvia Jáuregui Hodge M.Ed., Doctoral Fellow

Center for Equity for English Learners

Follow this and additional works at: https://digitalcommons.Imu.edu/ceelreports

Part of the Bilingual, Multilingual, and Multicultural Education Commons, Educational Administration and Supervision Commons, Educational Assessment, Evaluation, and Research Commons, and the Educational Leadership Commons

\section{Recommended Citation for Full Report}

Lavadenz, Magaly Ph.D., Professor; Armas, Elvira G. Ed.D., Associate Director; and Jáuregui Hodge, Sylvia M.Ed., Doctoral Fellow, Masking the Focus on English Learners: The Consequences of California's Accountability System Dashboard Results on Year 4 Local Control and Accountability Plans (LCAPs) (2018). doi: https://doi.org/10.15365/ceel.LCAP2018.1

This Book is brought to you for free and open access by the Center for Equity for English Learners at Digital Commons @ Loyola Marymount University and Loyola Law School. It has been accepted for inclusion in Reports by an authorized administrator of Digital Commons@Loyola Marymount University and Loyola Law School. For more information, please contact digitalcommons@lmu.edu. 


\section{ABOUT THE AUTHORS}

Magaly Lavadenz, Ph.D., is Distinguished Professor and founding Executive Director of the Center for Equity for English Learners in the School of Education at Loyola Marymount University. Her research addresses the intersections and impact of policies and practices for culturally and linguistically diverse students, their teachers and school leaders. She currently serves as President of Californians Together and has held leadership positions in numerous associations, including as past president of the California Association for Bilingual Education (CABE), the California Association for Bilingual Teacher Education and the California Council on Teacher Education. Her work is published in numerous articles, chapters and books, including Questioning our Practices: Bilingual Teacher-Researchers and Transformative Inquiry and Latino Civil Rights in Education: La Lucha Sigue, co-edited with Anaida Colón Muñiz.

Elvira G. Armas, Ed.D., is the Director of Programs and Partnerships for the Center for Equity for English Learners (CEEL) and Affiliated Faculty in the School of Education at Loyola Marymount University. Throughout her career, she has been actively engaged in collaborating with TK-12th grade educators to regularly explore the areas of leadership, curriculum, integrated standards-based instruction, assessment, and family/community engagement in culturally and linguistically diverse settings. She has served as a bilingual classroom teacher, mentor, district advisor, adjunct professor, staff developer, project director and curriculum materials developer. She has also co-authored several articles, policy briefs, and book chapters about issues related to teaching, learning, parent/community engagement, and assessment.

Sylvia Jáuregui Hodge, M.Ed., is completing her Doctorate in Educational Leadership for Social Justice at Loyola Marymount University, where she serves as the Doctoral Fellow at the Center for Equity for English Learners. She is a former educator having worked at highly-diverse, multilingual, Title I public schools in Texas. In 2014, she was awarded a fellowship from the National Head Start Association in Washington D.C., where she co-authored a report on successful two-generational approaches used by Head Start and Early Head Start programs. Her doctoral research focus is on school funding policies and how they affect the educational opportunities of English Learners.

\section{ACKNOWLEDGMENTS}

This report was made possible by the generous funding and support from the Sobrato Family Foundation and the California Community Foundation.

The authors are indebted to the reviewers who read the 24 Local Control and Accountability Plans (LCAPs) and rated them to support the findings in the report. Their names are listed in the Appendix.

Finally, Laurie Olsen, Californians Together Board Member and Special Advisor to the Sobrato Early Academic Language model, and Shelly Spiegel-Coleman, Executive Director of Californians Together, have provided invaluable support on the process for the LCAP reviews, the development of policy questions and recommendations. 


\section{TABLE OF CONTENTS}

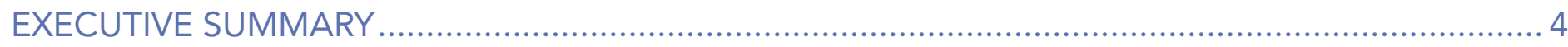

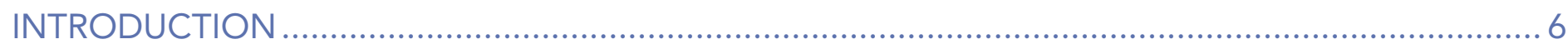

California's New English Learner Policy Context ................................................................................................... 7

The Intersect between the State Board of Education's English Learner

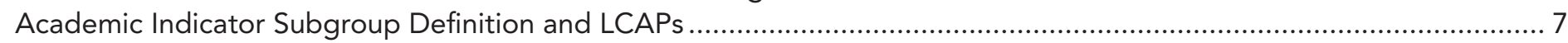

Table 1. ELA Academic Indicator English Learner Subgroup Performance ........................................................... 8

Figure 1. EL Yellow Subgroup Disaggregated ELO and RFEP Performance …………………………….......... 8

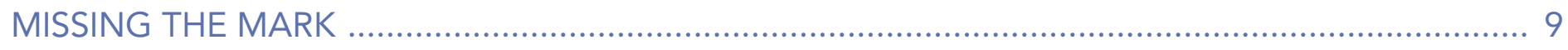

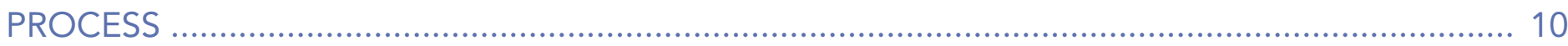

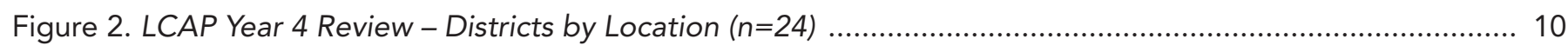

Table 2. LCAP English Learner Research-Aligned Rubrics - Selected Focus Areas and

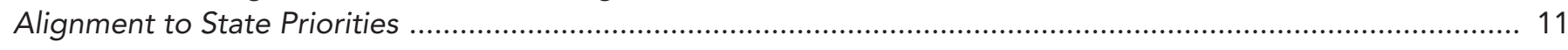

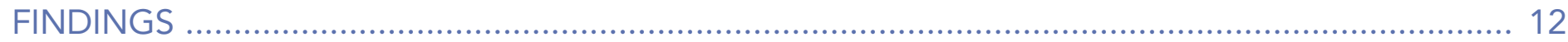

Figure 3. Year 4 LCAP Review - English Learner Research-Aligned Rubric Results

for Selected Districts $(n=24)$.............................................................................................................. 13

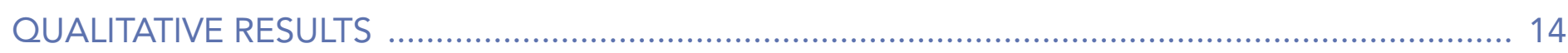

Undifferentiated Professional Learning for Teachers of English Learners ........................................................................ 14

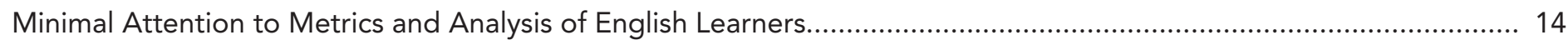

Inconsistent Services and Course Access for English Learners............................................................................... 15

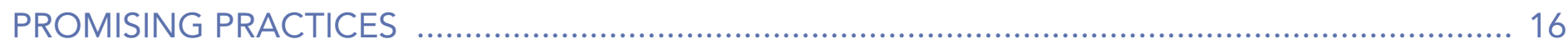

Table 3. Promising Practices for English Learners Documented in Sample LCAPs ................................................ 16

RECOMMENDATIONS - SHARPENING THE FOCUS ON ENGLISH LEARNERS .......................... 17

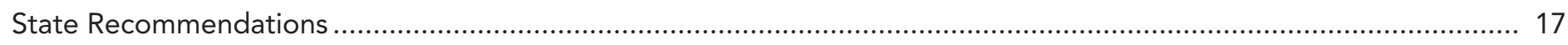

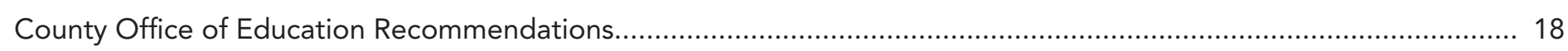

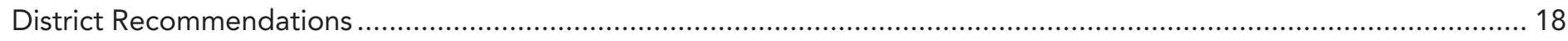

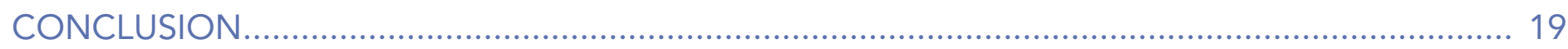

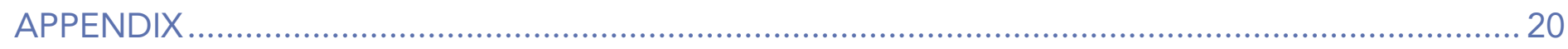

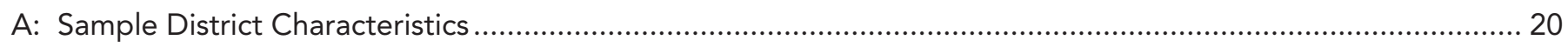

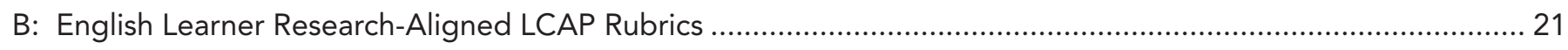

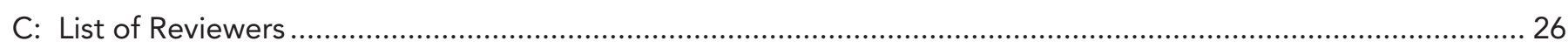

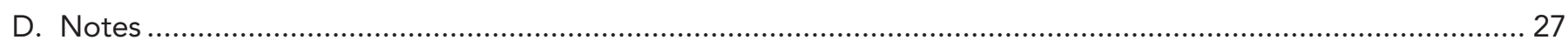




\section{KEY RECOMMENDATIONS}

\section{AT THE STATE LEVEL}

- Discontinue the use of the aggregated EL subgroup in the Academic Indicator.

- Report ELO data separately from RFEP data in a revised indicator, so as not to mask the needs and successes of the current ELs and RFEPs so that gaps and challenges can be addressed.

- Require districts to complete the Year 4 (2017-2020) LCAPs based on the revised indicators on the Dashboards' Five by Five Placement Grid for continuous improvement.

- Develop a robust system and processes for EL technical assistance providers for identified districts and schools with personnel that have EL expertise and experience with EL programs, curriculum, and instruction.

- Embed the English Learner Roadmap into the System of Support process.

- Build the capacity of County Offices of Education by increasing both program and personnel resources with EL expertise who read, review and support the development of LCAPs and provide technical assistance.

\section{AT THE COUNTY OFFICE OF EDUCATION LEVEL}

- Increase and involve staff with expertise on ELs to conduct the LCAP reviews and serve as members of the System of Support teams.

- Develop a data analysis process and work with districts to dig deeper into their ELO data.

- Include the critical areas in this report as part of the technical assistance and review offered to the districts which would require enhancing The LCAP Approval Manual to address these issues.

- Develop and use tools aligned to the English Learner Roadmap and the LCFF priority areas when providing technical assistance to schools and districts.

\section{AT THE DISTRICT LEVEL}

- Revise and update Year 4 (2017-2020) LCAPs using evidence from a self-analysis based on the researchaligned English Learner rubrics in Appendix B to identify areas of improvement.

- Identify specific outcomes for the different profiles of ELs with metrics that are sensitive to their language and academic development.

- Provide professional development for all educators on the implications of implementation of the English Learner Roadmap to build understanding and expertise about the needs of ELs and research-based practices.

- Ensure that professional learning for teachers of ELs addresses integrated and designated ELD as well as differentiation from generic standards-based instruction.

\section{CaliforniansTogether}

Championing the Success of English Learners

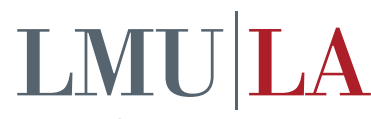

The Center for Equity

for English Learners 


\section{CALIFORNIA'S NEW ENGLISH LEARNER POLICY CONTEXT}

Committed to the moral and legal obligation to serve ELs effectively and emboldened by the leadership of champions for ELs at the local, state and national levels, California recently instituted two significant policy shifts to support research and evidenced-based comprehensive programs for ELs. The first was the passage of Proposition 58 (Nov. 2016) which reversed the English-only policy in educating the state's ELs to encouraging the state to offer multilingual programs leading to proficiency in English and another language for all students. The second major policy shift for ELs resulted in the adoption of the English Learner Roadmap (July 2017) ${ }^{4}$, intended to assist the California Department of Education (CDE) in guiding LEAs in "welcoming, understanding, and educating the diverse population of students who are English Learners." The English Learner Roadmap is based on four research-based core principles and specific elements that support high-quality programs for ELs, including bilingualism and biliteracy. LEAs have the opportunity to capitalize on these converging policies to honor their commitment to equity and to inform the development and monitoring of LCAPs to create a system that targets the specific needs of ELs.

\section{THE INTERSECT BETWEEN THE STATE BOARD OF EDUCATION'S ENGLISH LEARNER ACADEMIC INDICATOR SUBGROUP DEFINITION AND LCAPS}

In 2016 the State Board of Education (SBE) decided to include two years of English Learners Only (ELO) and four years of Reclassified Fluent English Proficient (RFEP) student data in a composite English Learner (EL) subgroup for the Academic Indicator on the Spring 2017 Dashboard. The state's decision to not consider the diversity of ELs in the accountability system proves challenging and has long-lasting implications for state and district-level decisions in learning how to target technical assistance and interventions for all ELs. Most importantly, the aggregated results from the Dashboard could potentially mask the results for English Learner Only students, including the various EL profiles (i.e., LTELs, newcomers, etc.). Obscuring ELO results could have detrimental effects on districts' abilities to address LCAP goals, set growth targets, focus programs and services, and allocate supplemental and concentration funds for this targeted group of students. Accordingly, our past analyses have shown that the state's LCAP guidance and the LCAPs have not sufficiently addressed the needs of ELs. ${ }^{5}$

The Year 4 LCAP template, which addresses a threeyear time span from 2017-2018 through the 2019-2020 academic years, was revised to include descriptive sections where districts can highlight accomplishments and identify performance gaps. This revision has the potential to increase equity by explicitly asking districts to identify needs directly linked to subgroups that fall within the lowest two performance levels on the Dashboard - the Orange or Red bands of achievement. However, the 2016 EL subgroup definition (ELO + RFEP) was identified as problematic in this process, as espoused by a large contingent of organizations, schools, districts, and researchers who contended that this definition would mask the needs of ELOs by calculating the average of the data from both groups. In addition, a brief written by three researchers with EL expertise was presented to the State Board of Education describing the potential negative consequences of this proposal ${ }^{6}$.

The brief acknowledged that while including ELO and RFEP data is essential for long-term program evaluation, three-year district LCAPs rely on current Dashboard data in identifying needed programs and services for targeted subgroups. As stated previously, the Spring 2017 Dashboard Academic Indicator EL subgroup consists of two years of ELO and four years of RFEP student data. This is problematic for districts and local stakeholders when deciding student priorities in the LCAP. As well, the combined ELO + RFEP subgroup resulted in the vast majority of districts falling within the Yellow, Green, or Blue bands in the Academic Indicator for ELs. These results could potentially fail to address the needs of ELs and exclude them from receiving technical assistance and financial support in their LCAPs.

California embarked on a historical and bold effort to implement the Local Control Funding Formula (LCFF) - an education finance reform intended to foster equity alongside local flexibility and democratic engagement. 
The concerns expressed to the State Board of Education were corroborated through our analysis of the Spring 2017 Dashboard Academic Indicator for English Language Arts (ELA) ${ }^{7}$, which includes 2015 and 2016 results from the Grades 3-8 California Assessment of Student Performance and Progress (CAASPP). ${ }^{7}$ A total of 869 non-charter public LEAs yielded results for the ELA Academic Indicator ${ }^{8}$. Of these, 807 had an EL subgroup, which consists of an aggregate of the ELO and RFEP student subgroups. Ultimately only 680 LEAs met two additional criteria to identify a viable EL subgroup: 1) minimum number of students to protect anonymity; and 2) a total of 2-4 years of previous data. Table 1 provides an overview of the performance levels for EL subgroups on the ELA Academic Indicator as reported in the Spring 2017 Dashboard. ${ }^{9}$

TABLE 1: ELA Academic Indicator English Learner Subgroup Performance

\begin{tabular}{|l|c|c|}
\hline \multicolumn{1}{|c|}{ Performance Level Color } & \#LEAs w/EL Subgroup ( $n=680)$ & \% of Total \\
\hline BLUE (Highest Performance) & 21 & $3.09 \%$ \\
\hline GREEN & 61 & $8.97 \%$ \\
\hline YELLOW & 462 & $67.94 \%$ \\
\hline ORANGE & 63 & $9.26 \%$ \\
\hline RED (Lowest Performance) & 73 & $10.74 \%$ \\
\hline
\end{tabular}

A majority of EL subgroups (ELO + RFEP) identified in the Yellow performance level (67.94\%) on the ELA Academic Indicator. Of the 462 EL subgroups classified in the Yellow performance level, 436 had ELO subgroups, and 416 had RFEP subgroups with student populations of 11 or more. ${ }^{10} \mathrm{~A}$ comparison of the two subsets shows that ELO subgroups overwhelmingly identified in the two lowest performance levels (Orange or Red) when compared to RFEP subgroups, $65 \%$ versus $5 \%$, respectively (see Figure 1). Furthermore, there were no districts which had ELOs at highest performance levels (Green and Blue). Because the EL subgroup is comprised of ELO and RFEP subgroups, a majority of districts 283 of 462 , or $61.3 \%$ - were identified by the accountability system in the Yellow performance level for the Academic Indicator, which is detrimental for ELOs. By receiving a Yellow performance level, 283 districts were automatically excluded from Technical Assistance or Intensive Intervention by the State Board of Education and their Academic Indicator for ELs was not triggered as a threshold to be addressed in subsequent LCAP years.

FIGURE 1: EL Yellow Subgroup* Disaggregated by ELO and RFEP Performance

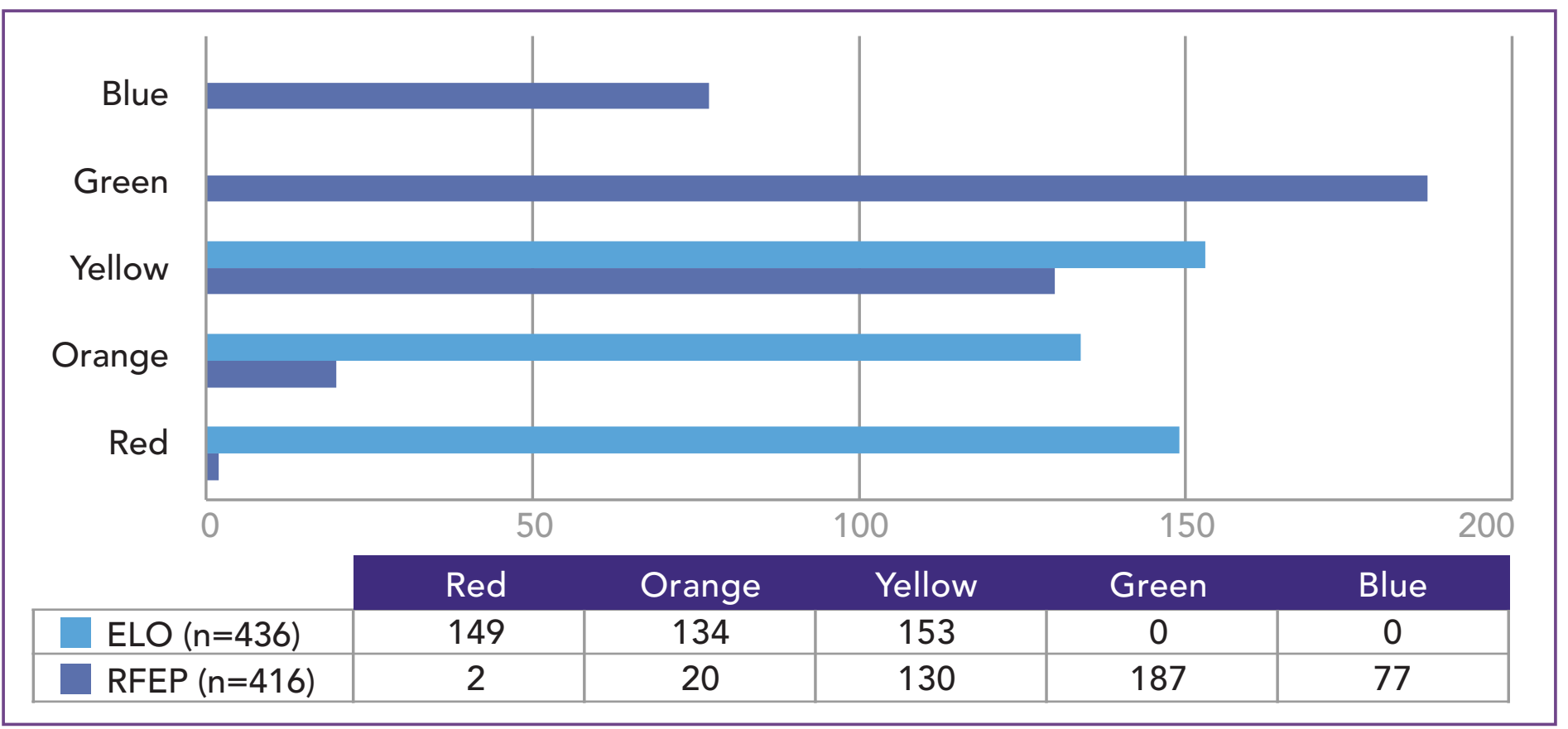

*See Table 1. EL-ELA Academic Indicator English Learner Subgroup Performance 


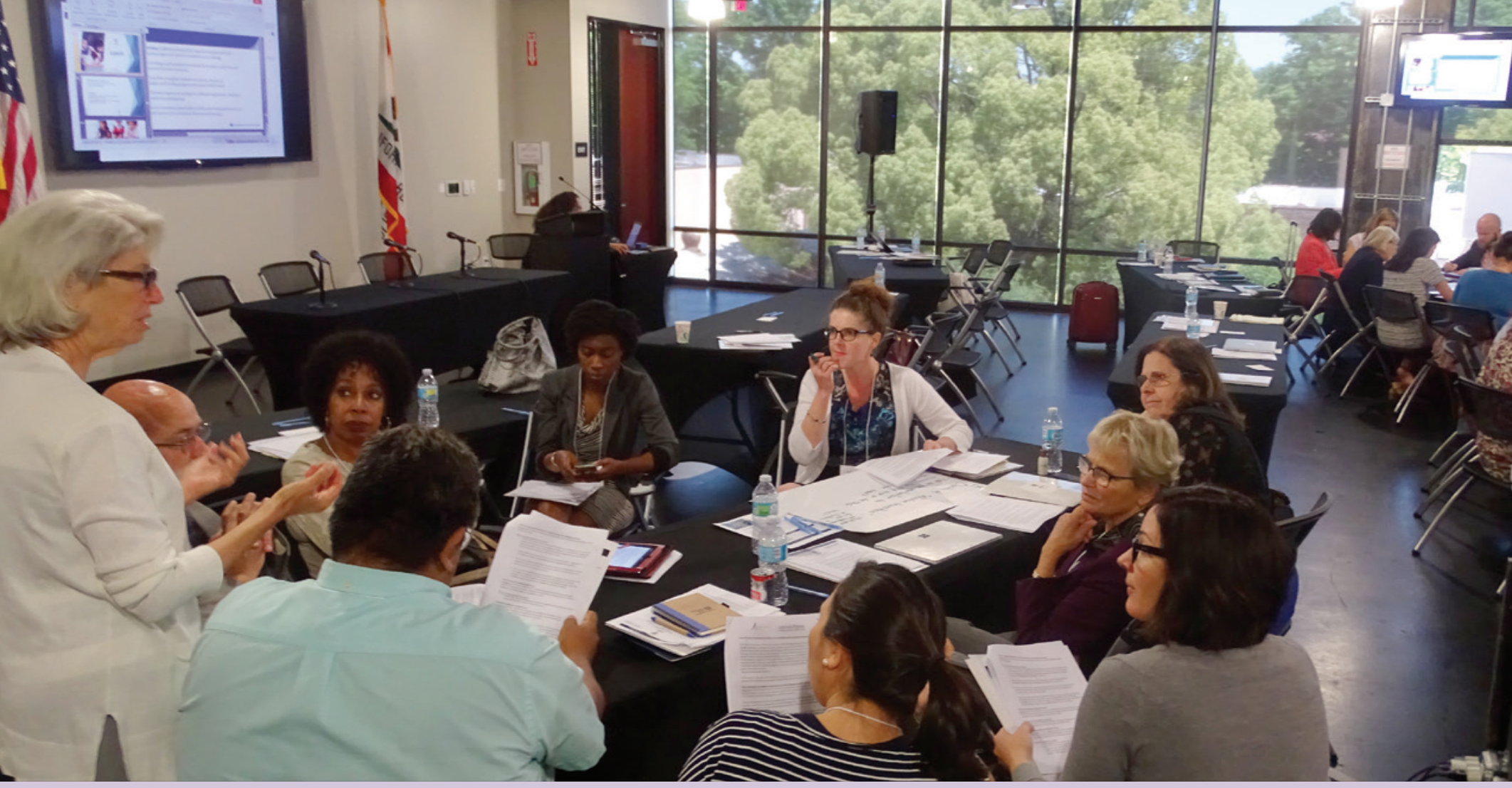

\section{MISSING THE MARK}

Through these findings, we conclude that the current California accountability system will diminish the urgency to address the educational needs of the ELO subgroup and thus further undermine the equity intent of LCFF. There is great potential for California school districts to be misled by the results of the combined English Learner subgroup Dashboard Academic Indicator performance levels. The misleading results of Dashboard outcomes and the subsequent connections to LCAP inputs usher in a school reform era that can likely leave ELs, along with reclassified ELs, behind. The decision to combine ELO and RFEP students - two student groups with distinct language and academic profiles - to calculate the Dashboard Academic Indicator Performance Levels for the EL subgroup may indeed mask access to programs and services needed by many ELs. Given that California's new accountability system is designed as a driver for continuous improvement ${ }^{11}$, the focus needed for LEAs to respond to the diverse needs of ELs in their districts is imperative.

The next phase of our work was to examine the impact of these Spring 2017 Dashboard results on Year 4 LCAPs (covering the 2017-18, 2018-19, and
2019-20 academic years). We identified and reviewed district LCAPs with an overall English Learner (ELO + RFEP) ELA Academic Performance Level of Yellow, AND whose ELO level was Orange or Red. The Yellow designation does not trigger a response on the LCAP nor signal technical assistance; neither does it preclude a district from focusing on their ELOs (especially when disaggregated results reveal a much lower ELO Academic Indicator status). Districts can and should take a more in-depth approach to shine a light on the needs of this population, often also comprised of LTELs and newcomers. Accordingly, this focus on ELs would be expected to highlight evidence in the LCAPs of increased comprehensive programming and services for all EL subgroups.

Two critical questions guided this review:

1 For districts whose ELA-EL academic performance level is Yellow on the Spring 2017 California School Dashboard, what evidence exists for comprehensive programs for English Learners in the districts' LCAPs?

2 For these same districts, what evidence exists about increased or improved services for English Learners? 


\section{PROCESS}

Beginning with the Spring 2017 Dashboard results, we used a stratified purposeful sampling strategy to select 24 districts with Yellow EL-ELA status and an ELO level of Orange or Red. These districts represent a variety of geographic locations across the state (city, suburban, and rural locations). Of the 24 districts, 11 districts have high numbers of ELs (HN), 11 districts have a high percentage of ELs $(\mathrm{HP})$, and 2 have both HN and HP of ELs (see Figure 2). Altogether, these districts serve $308,226 \mathrm{ELs}$, or approximately 23 percent of ELs in California.
In January 2018, a panel of 26 reviewers representing a cross-section of the California educational community convened to review the fourth year LCAPs (See Appendix C for a list of the reviewers). The group reviewed: a) the history of LCAP plan development and its changes; b) the intent of the LCAP and its requirements; c) California's accountability system and how it applies to ELs; and d) the identification process for sample districts. The rationale for the use of the five priority rubrics from the original ten English Learner

FIGURE 2: LCAP Year 4 Review - Districts by Location $(n=24)$

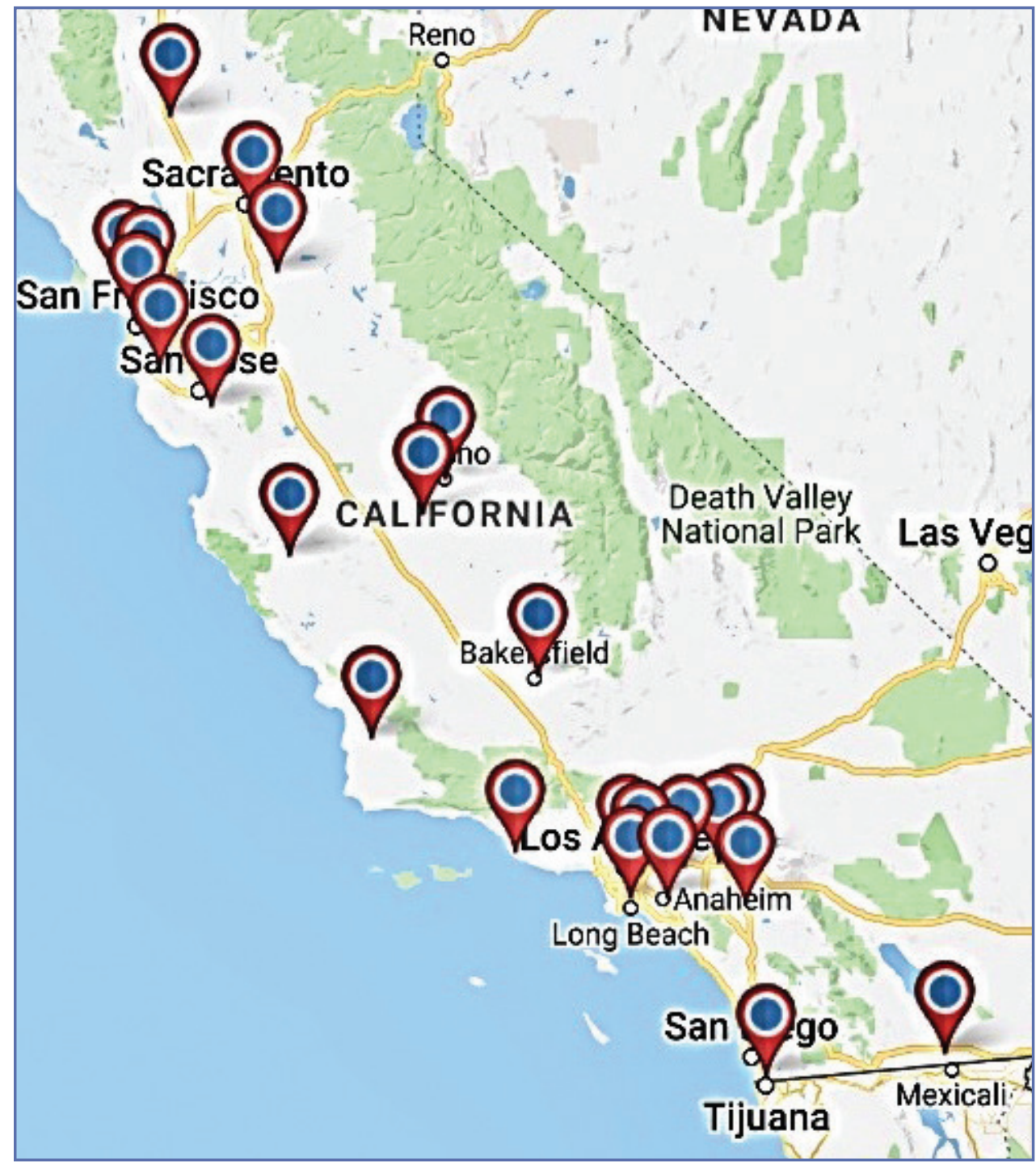


Research-Aligned LCAP Rubrics ${ }^{12}$ was also discussed and agreed upon by the reviewers. Together these rubrics represent key facets of comprehensive programs for ELs. Each of the five priority rubrics (see Table 2) were presented, and sample indicators explained across a four-point rating scale ranging from low to high: No Evidence Included, Weak, Good, and Exemplary.

TABLE 2: LCAP English Learner Research-Aligned Rubrics - Selected Focus Areas and Alignment to State Priorities

\begin{tabular}{|c|c|c|}
\hline State Priorities* & Focus Area & Focus Area Categories \\
\hline 2 & $\begin{array}{l}\text { RUBRIC \#1: } \\
\text { English Language } \\
\text { Development (ELD) }\end{array}$ & $\begin{array}{l}\text { - Designated \& Integrated Program } \\
\text { - ELD Standards } \\
\text { - ELD Standards Implementation } \\
\text { - ELD Standards PD }\end{array}$ \\
\hline 2,6 & $\begin{array}{l}\text { RUBRIC \#3 } \\
\text { Professional } \\
\text { Development (PD) }\end{array}$ & $\begin{array}{l}\text { - PD Stakeholder Input } \\
\text { - Comprehensive PD Program for Teachers of ELs } \\
\text { - PD Content } \\
\text { - PD Cultural Proficiency/Competency }\end{array}$ \\
\hline 2,7 & $\begin{array}{l}\text { RUBRIC \#4: } \\
\text { Program \& Course } \\
\text { Access }\end{array}$ & $\begin{array}{l}\text { - Preschool } \\
\text { - Access to Rigorous Core Content } \\
\text { - LTEL Courses } \\
\text { - Enrichment and/or Extracurricular Opportunities } \\
\text { - Extended Learning }\end{array}$ \\
\hline $2,4,7,8$ & $\begin{array}{l}\text { RUBRIC \#7 } \\
\text { Actions \& Services }\end{array}$ & $\begin{array}{l}\text { - Responsiveness to EL Profiles } \\
\text { - Assessment-Based Placement and Services } \\
\text { - Program Options } \\
\text { - Targeted Use of Supplemental and Concentration Funds }\end{array}$ \\
\hline $4,5,8$ & $\begin{array}{l}\text { RUBRIC \#10B } \\
\text { Student Outcomes }\end{array}$ & $\begin{array}{l}\text { - L1/L2 Data Reporting } \\
\text { - GAP Reporting } \\
\text { - Transcript Evaluation (high school only) } \\
\text { - Increase in Seal of Biliteracy, Pathway Awards }\end{array}$ \\
\hline
\end{tabular}

*State priorities for Local Control and Accountability Plan (LCAP)

1 - Basic (Conditions of Learning); 2 - State Standards (Conditions of Learning); 3- Parental Involvement (Engagement); 4- Pupil Achievement (Pupil Outcomes); 5- Pupil Engagement (Engagement); 6 - School Climate (Engagement); 7 - Course Access (Conditions of Learning); 8 - Other Pupil Outcomes (Pupil Outcomes)

Note. $L 1=$ Native language, home language; $L 2=$ non-native language; GAP = Achievement gap; LTEL = Long-Term English Learner.

A sample district LCAP provided the basis for group rating and was used to establish inter-rater reliability ensuring consistent application of the rubric indicators. Two reviewers read the same LCAP in its entirety, and then the pair of reviewers agreed upon a consensus rating for each indicator on all rubrics. Review panel members recorded sample evidence statements to support rubric ratings. A research team at Loyola Marymount University's Center for Equity for English Learners compiled all rubric scores to identify patterns, trends, and identifiable evidence of increased or improved services for ELs based on each of the five rubrics. 


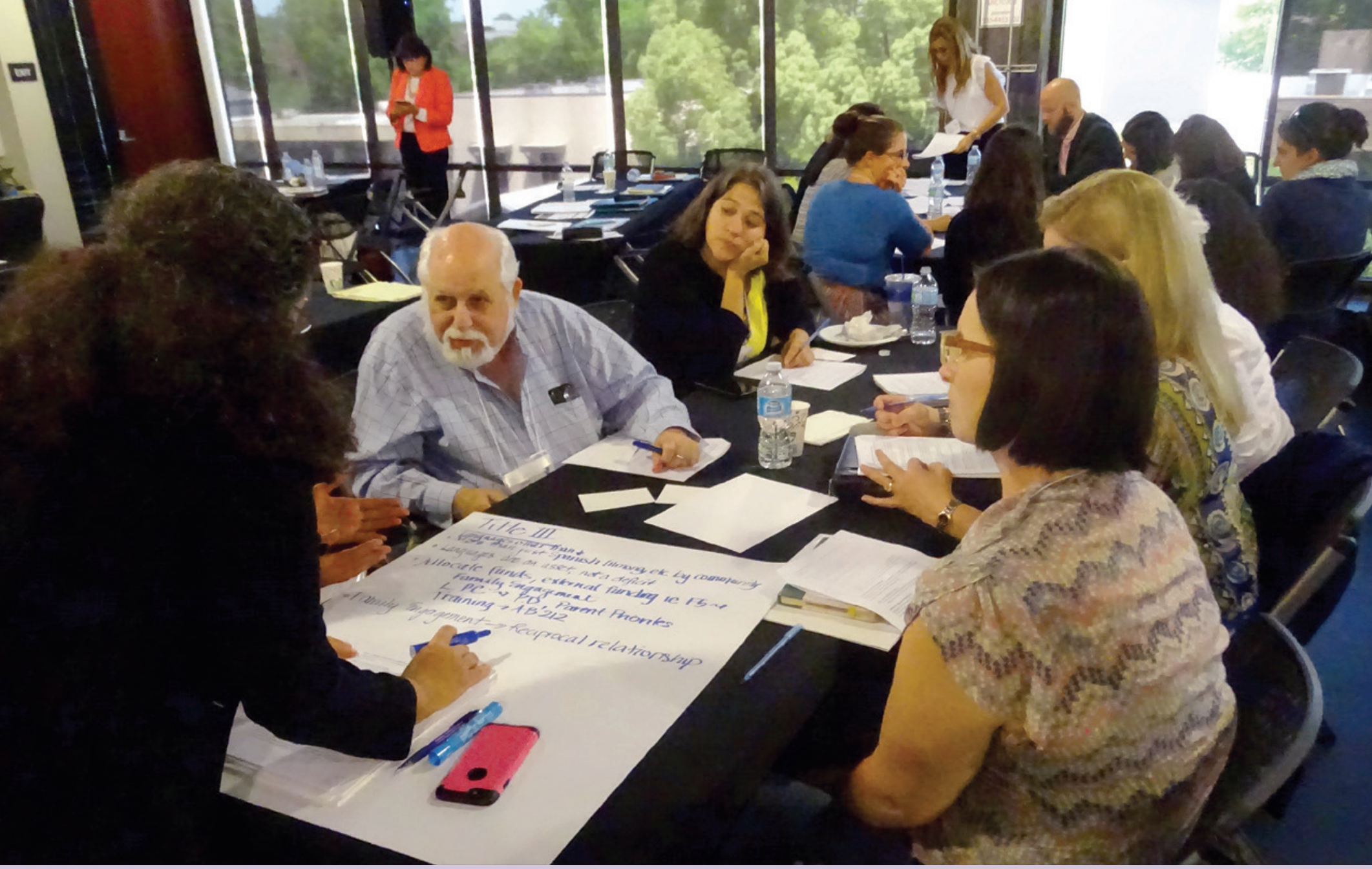

\section{FINDINGS}

The Year 4 LCAP review reflected a slight decrease in the number and percentage of districts that received overall No Evidence Included and Weak ratings and a slight overall increase in Good ratings when compared to the previous LCAPs review reports. ${ }^{5}$ Across all 24 LCAPs, we found only three LCAPs that were rated Exemplary in the English Language Development (Rubric 1) and Professional Development (Rubric 3) focus areas, and only one that was rated No Evidence Included in Programs and Course Access (Rubric 4)

An overwhelming majority, 22 out of 24 LCAPs (92\%), had ratings of Weak or No Evidence Included in the English Learner Student Outcomes focus area, underscoring the lack of equity goals/ outcomes for English Learners. focus area. An overwhelming majority, 22 out of 24 LCAPs (92\%), had ratings of Weak or No Evidence Included in the English Learner Student Outcomes (Rubric 10B) focus area, underscoring the lack of equity goals/outcomes for ELs. Over half of the districts had overall weak ratings in the following three areas: 1) English Language Development ( $n=13)$; 2) Professional Development ( $n=13)$; and 3) Programs and Course Access $(n=12)$. In fact, there was no single district from the 24 reviewed that had evidence of Exemplary or Good ratings across all five focus areas. These results imply a lack of district systemic approaches to articulating local policies and practices based on research for improving English Learner achievement and the consequences of how California's current accountability system masks the needs for ELs, particularly in the sample of districts that were purposefully selected on the criteria of high numbers and/or high percentages of English Learners. [See Figure 3 for the English Learner Research-Aligned Rubric Results for Selected Districts.] 
FIGURE 3: Year 4 LCAP Review - English Learner Research-Aligned Rubric Results for Selected Districts ( $N=24)$

\section{FOCUS AREAS}

RUBRIC \#1:

English Language

Development (ELD)

RUBRIC \#3

Professional

Development (PD)

RUBRIC \#4:

Program \&

Course Access

RUBRIC \#7

Actions \& Services

RUBRIC \#10B

Student Outcomes

\section{RATINGS SCALE}

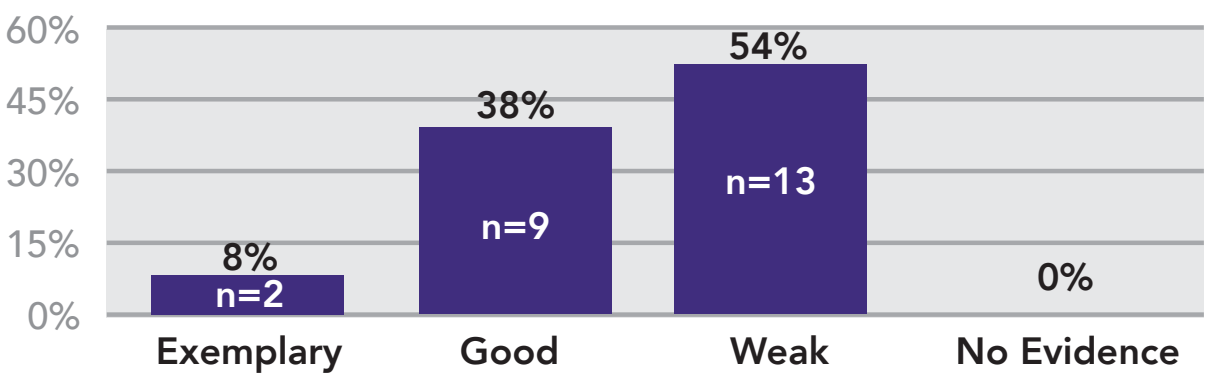

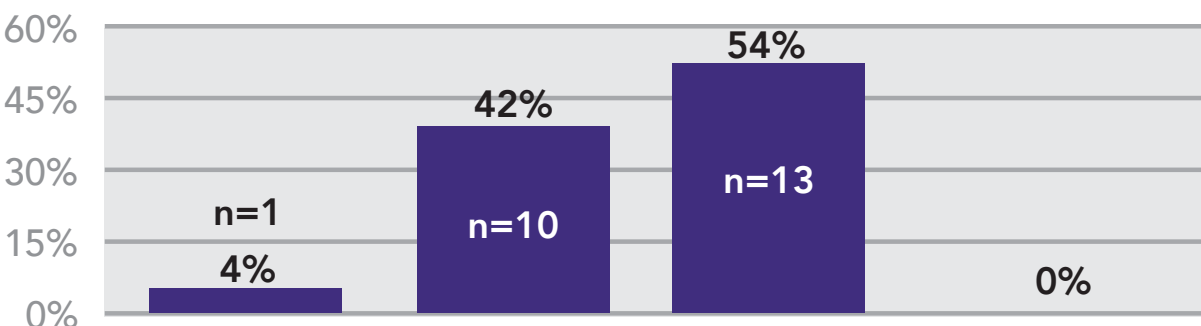

Exemplary Good Weak No Evidence

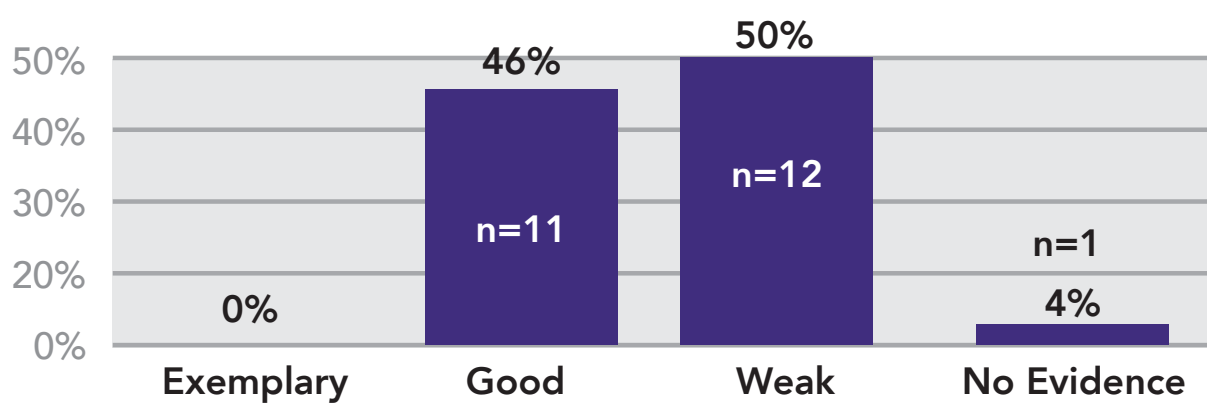

$60 \%$

$58 \%$

$45 \%$

$30 \%$

$15 \%$

$0 \%$
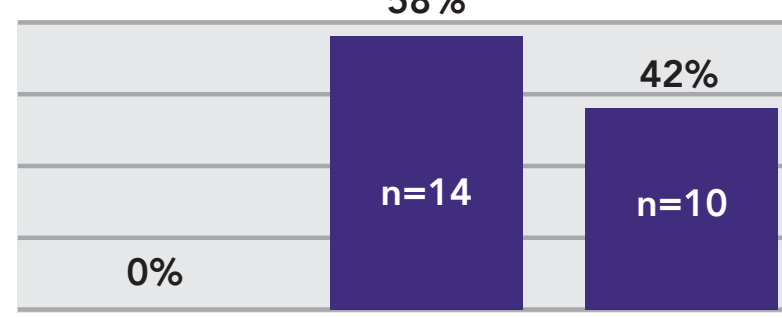

No Evidence

$80 \%$

$60 \%$

$40 \%$

$20 \%$

$0 \%$

Weak

$79 \%$

\section{Good}

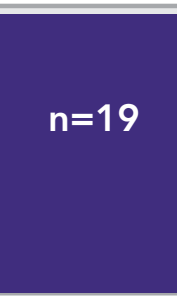

Weak

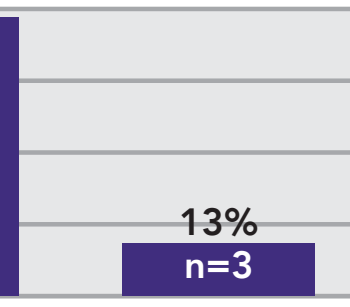

No Evidence 

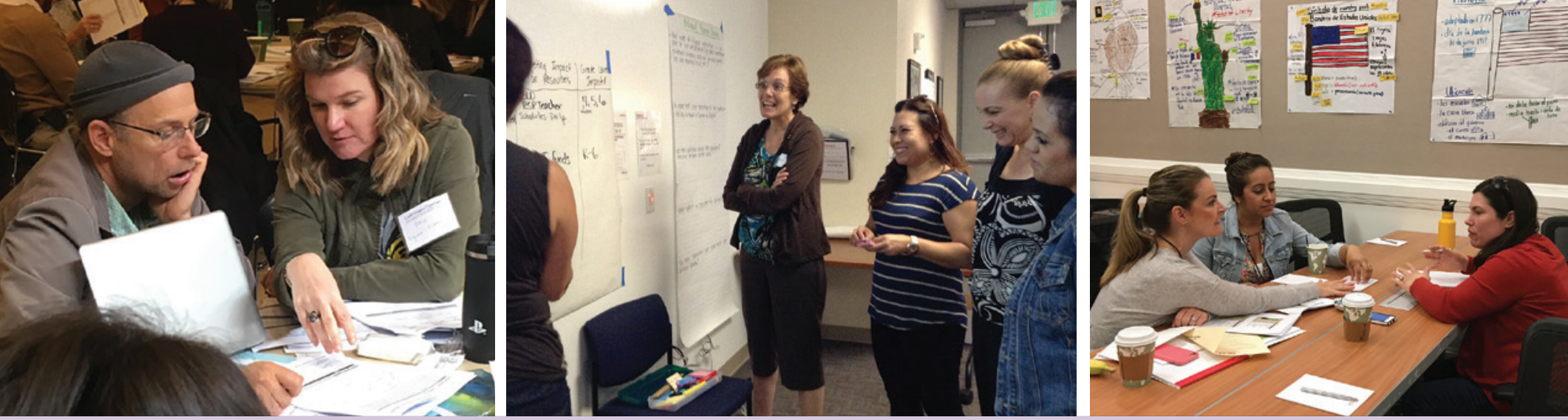

\section{QUALITATIVE RESULTS}

The Year 4 LCAP template afforded LEAs the opportunity to orient readers to their overall plans in several introductory sections: 1) LCAP Highlights; 2) Areas of Greatest Progress; 3) Greatest Needs; and 4) Performance Gaps. We conducted a content review of these three sections to determine: a) Did district LCAPs address the needs of ELO students?; and b) Were Dashboard results mentioned explicitly in Year 4 LCAPs for ELs with regard to ELA academic achievement? If so, were these data also examined for ELO students in order to identify specific action steps for increased or improved services?

The analysis of the aforementioned introductory sections revealed the following:

- Half ( $n=12)$ of the reviewed LCAPs discussed only the English Learner Progress Indicator - not ELA Achievement - as an area of concern for ELs. ${ }^{13}$

- Only one-fourth $(n=6)$ of the reviewed LCAPs mentioned a concern for the ELA achievement of ELs.

- Only 1 of 24 districts specified a concern for the academic achievement of ELO students.

There is clear evidence that the Dashboard EL Academic Indicator masks the needs of ELOs and the accountability system appears to fail in focusing attention, awareness, and generating responsiveness to the needs of this diverse group. This is further corroborated by results from the analysis of evidence produced by the reviewers' rating of the full LCAPs, which revealed several trends and patterns for each of the five rubrics.
The following themes emerged from these analyses:

\section{UNDIFFERENTIATED PROFESSIONAL LEARNING FOR TEACHERS OF ENGLISH LEARNERS}

There was minimal evidence of districts' approaches to differentiating professional learning for teachers of English Learners concerning content and language development standards, instruction, or cultural proficiency training. In many LCAPs, general descriptions of professional development services for teachers of ELs prevailed with only some mention of specific plans for sustained learning opportunities (e.g. collaboration, coaching, teacher reflection, inquiry cycles) for implementing evidence-based strategies for designated and integrated ELD. The same was true for setting priorities for ELD standards implementation based on student language proficiency and academic data. These findings echoed those from previous LCAP analyses. There were few promising practices identified and, in few instances, some districts identified utilizing cultural competency training. When considering the dire need for highly qualified teachers that are trained to meet the needs of ELs, the lack of differentiated professional learning is alarming.

\section{MINIMAL ATTENTION TO METRICS AND ANALYSIS OF ENGLISH LEARNER OUTCOMES}

Very few districts identified EL specific metrics beyond the required reclassification, CELDT or SBAC metrics. Additionally, growth measures overwhelmingly mentioned ELs as an aggregate subgroup rather than identifying growth targets for various EL typologies such 


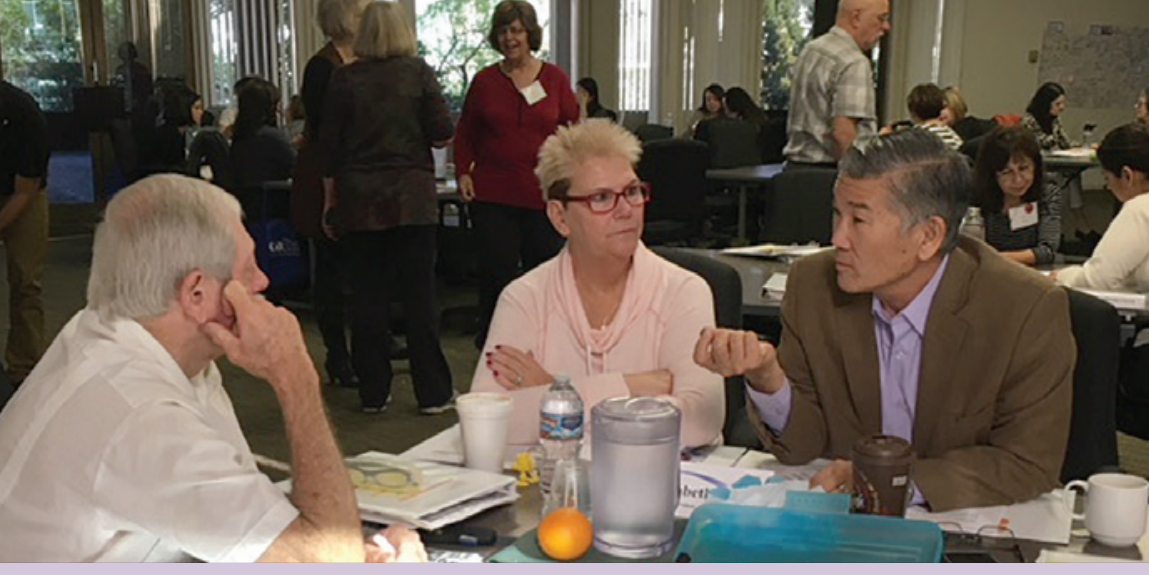

as students at-risk of becoming LTELs, or newcomers. In the few cases where additional EL-specific metrics were identified, these included the Seal of Biliteracy, district or site-adopted assessments such as the ADEPT (A Developmental English Proficiency Test), or assessments included in state-adopted materials. Very few LCAPs identified primary language assessments for ELs.

\section{INCONSISTENT SERVICES AND COURSE ACCESS FOR ENGLISH LEARNERS}

Although many LCAPs mentioned LTELs and newcomers, the description of specialized ELD or programs for these groups of students lacked clarity in many plans, and there was minimal mention of the role of primary language for instruction or assessment. Few LCAPs described how access to enrichment and/or extracurricular opportunities are promoted and monitored. Often descriptions of improved or increased services provided through supplemental and concentration funding focused on the continuation of staff, or additional staff to serve ELs, including EL Coordinators, bilingual TOSAs (Teachers on Special Assignment), or bilingual paraprofessionals. In many cases, the rationale for this staffing was to provide intervention or extended services, rather than to develop asset-based approaches to curriculum and instruction.

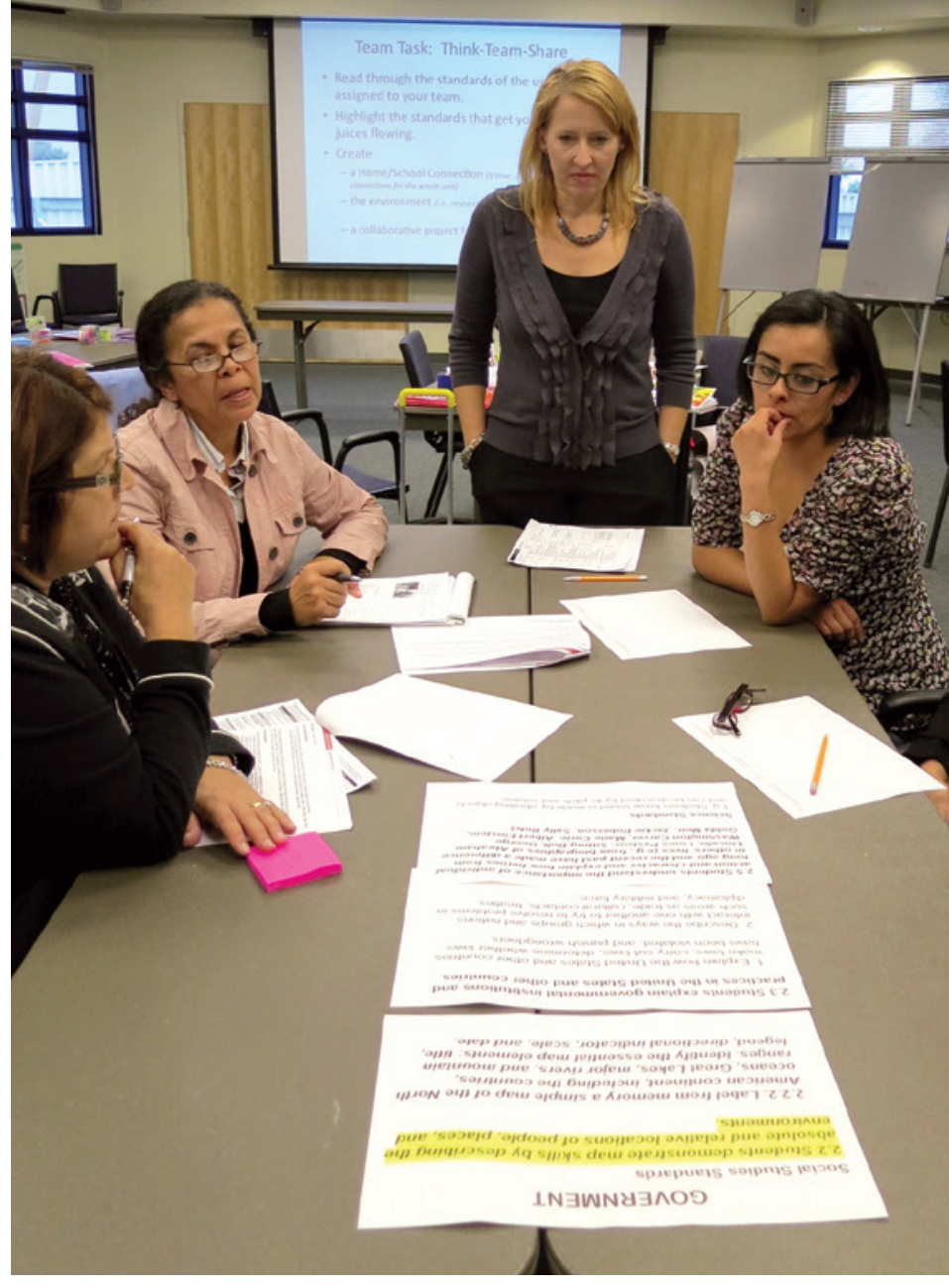

There is clear evidence that the Dashboard EL Academic Indicator masks the needs of ELOs and the accountability system appears to fail in focusing attention, awareness, and generating responsiveness to the needs of this diverse group.

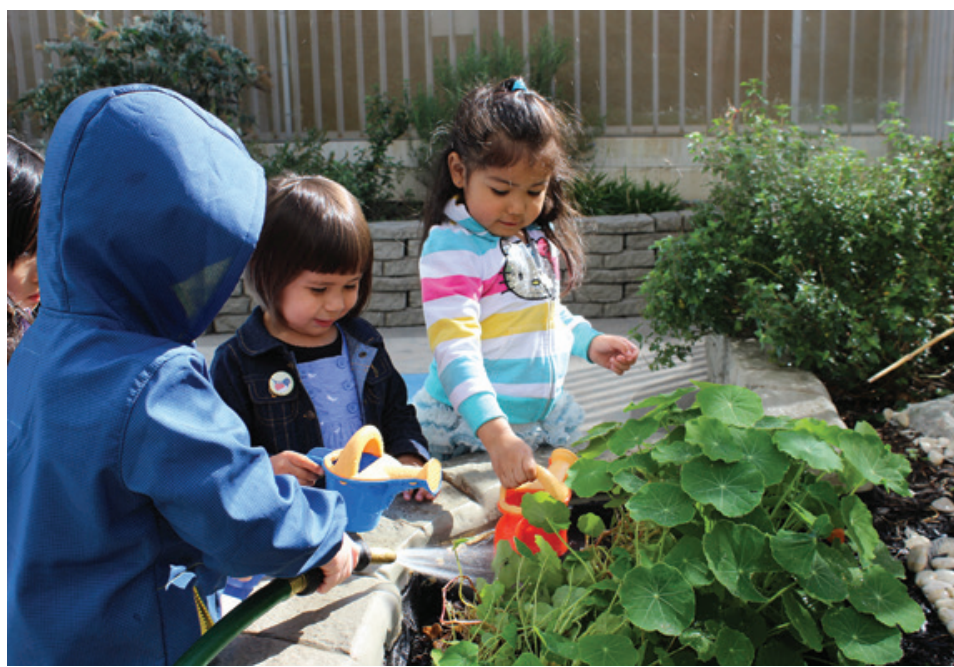




\section{PROMISING PRACTICES}

District LCAPs were also analyzed for examples of research-based, promising practices in serving ELs (see Table 3) $)^{14}$. These practices signal districts' slow progress towards seizing the opportunity to provide equitable educational programs to ELs. The methods highlighted reflect inclusive practices, which are primarily proactive rather than reactive. In other words, while it is best practice to provide research-based interventions to ELs, interventions should not be the only educational opportunities available and documented in the LCAP. Instead, asset-based approaches, such as those that expand the knowledge and skills of linguistically diverse students, should be the foundation of the educational programs available to this historically underserved group.

TABLE 3: Promising Practices for English Learners Documented in Sample LCAPs

\begin{tabular}{|c|c|c|}
\hline Focus Area Rubrics & Focus Area Categories & Promising Practices \\
\hline \multirow[t]{2}{*}{$\begin{array}{l}\text { RUBRIC \#1: } \\
\text { English Language } \\
\text { Development (ELD) }\end{array}$} & $\begin{array}{l}\text { Designated and } \\
\text { Integrated Program }\end{array}$ & $\begin{array}{l}\text { Rubric created for schools to use as guidance on daily lesson } \\
\text { expectations for implementing a Designated and Integrated ELD } \\
\text { program. } \\
\text { Implementation and expansion of the Sobrato Early Academic } \\
\text { Language Program, an intensive professional development for } \\
\text { teachers of ELs; Formation of EL Taskforce to address EL needs. } \\
\text { Staff Development coaches provided teachers with support in } \\
\text { providing ELs with Designated and Integrated ELD using Sobrato } \\
\text { Early Academic Learning Program units and strategies. }\end{array}$ \\
\hline & ELD Standards & $\begin{array}{l}\text { Kagan cooperative learning strategies training in the area of ELD } \\
\text { for all teachers and training instructional aides on how to best } \\
\text { provide support to EL students. }\end{array}$ \\
\hline \multirow[b]{2}{*}{$\begin{array}{l}\text { RUBRIC \#3: } \\
\text { Professional } \\
\text { Development (PD) }\end{array}$} & PD Stakeholder Input & $\begin{array}{l}\text { ELD Director conducted needs assessment for PD with } \\
\text { administration, teachers \& staff to identify learning needs. }\end{array}$ \\
\hline & PD Content & $\begin{array}{l}\text { All new teachers received special training in teaching ELs, unit/ } \\
\text { lesson planning using academic vocabulary an EL instructional } \\
\text { strategies. } \\
\text { Bilingual classified staff received PD on reteaching in small } \\
\text { groups, intervention strategies, and translating and interpreting } \\
\text { for non-bilingual certificated staff. }\end{array}$ \\
\hline $\begin{array}{l}\text { RUBRIC \#4: } \\
\text { Programs and } \\
\text { Course Access }\end{array}$ & $\begin{array}{l}\text { Access to Rigorous } \\
\text { Core Content }\end{array}$ & $\begin{array}{l}\text { Middle School program was redesigned as a response to ELs } \\
\text { lack of access to a broad course of study due to participating } \\
\text { in intervention classes. With the redesign, ELs have access to } \\
\text { electives and still receive the interventions needed. } \\
\text { Ensure that all schools have effective and equitable bilingual aide } \\
\text { support for ELs. } \\
\text { A number of districts documented their efforts in establishing } \\
\text { bilingual and dual language programs. Some LCAPs detailed } \\
\text { strategic partnerships and steps to ensure the success of the new } \\
\text { programs, with plans to expand in the following school years. }\end{array}$ \\
\hline
\end{tabular}




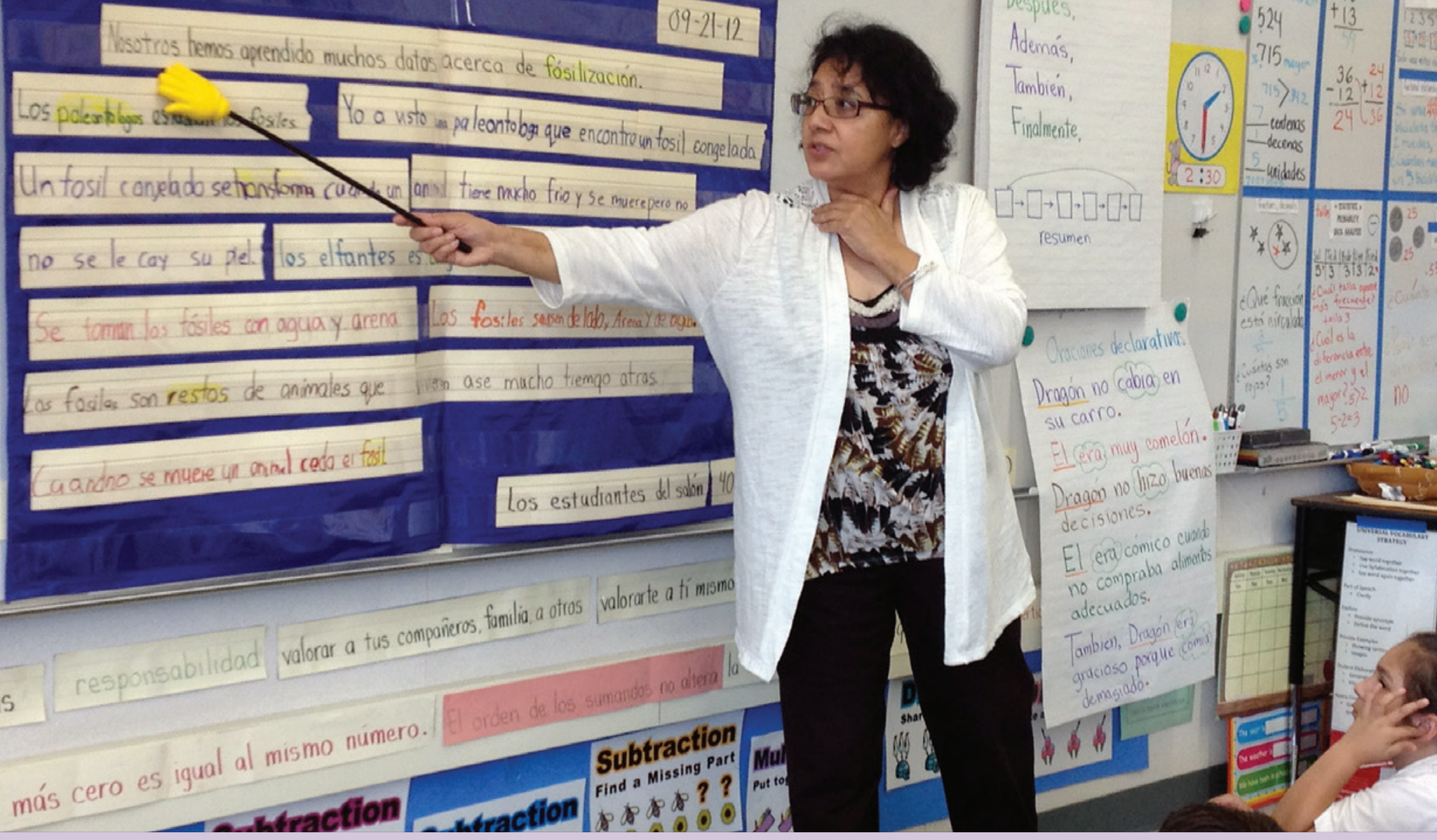

\section{RECOMMENDATIONS \\ SHARPENING THE FOCUS ON ENGLISH LEARNERS}

To adequately address the needs of ELs, our state accountability system and each level of the educational system must sharpen the focus on current English Learners' diverse needs. Simultaneously, our system should recognize, acknowledge and reward districts who make strides with their RFEP students and ensure their continued success. As it is currently constructed, the Academic Indicator aggregate EL subgroup (ELO+RFEP) masks the needs and weakens the focus on ELO students. A series of recommendations for the state, county office of education, and district levels follow.

\section{STATE RECOMMENDATIONS}

- Discontinue the use of the aggregated EL subgroup in the Academic Indicator. Report ELO data separately from RFEP data so as not to mask the needs of the current ELs and instead highlight the gaps and challenges that should be addressed.

- Redesign the EL Academic Indicator.

- Require districts to complete the LCAP (2017-2020) annual updates based on the revised indicator on the Dashboards' Five by Five Placement Grid for continuous improvement. This will allow districts to address the changing needs of the diverse EL subgroups.
- Establish guidelines for the implementation of the English Learner Roadmap as a key policy mechanism to create research-based reforms for EL education in the state to inform the LCAPs through the:

- Development of district and school site knowledge base of the principles and elements of the English Learner Roadmap to serve as guidance needed for reforms and increased or improved EL services.

- System of Support providers, the CDE, California Collaborative for Educational Excellence (CCEE) and California County Superintendents Educational Services Association (CCSESA) should also be knowledgeable and confident to use the English Learner Roadmap when providing technical assistance to districts and schools. 
- Coordinate the continuous improvement work of the CDE, CCEE, CCSESA and other agencies to ensure that accelerated achievement expectations for EL outcomes result in closing achievement gaps.

- Develop a robust system and processes for EL technical assistance providers for identified districts and schools with personnel that have EL expertise and experience with EL programs, curriculum, and instruction.

- Require that EL support providers work with districts and schools to dig deeper into the EL data focused on various EL profiles including students-at-risk of becoming LTEL, and newcomers.

- Build the capacity of County Offices of Education by increasing both program and personnel resources with EL expertise who read and support the development of LCAPs and provide technical assistance.

- Provide support for development of multilingual programs to promote high levels of proficiency in English and another language.

\section{COUNTY OFFICE OF EDUCATION RECOMMENDATIONS}

- Increase and involve staff with expertise on ELs to conduct the LCAP reviews and serve as members of the System of Support teams.

- Develop a data analysis process (e.g. the San Diego County Office of Education English Learner Dashboard) and work with districts to dig deeper into their ELO data to identify programs and services to support language development and close opportunity and achievement gaps.

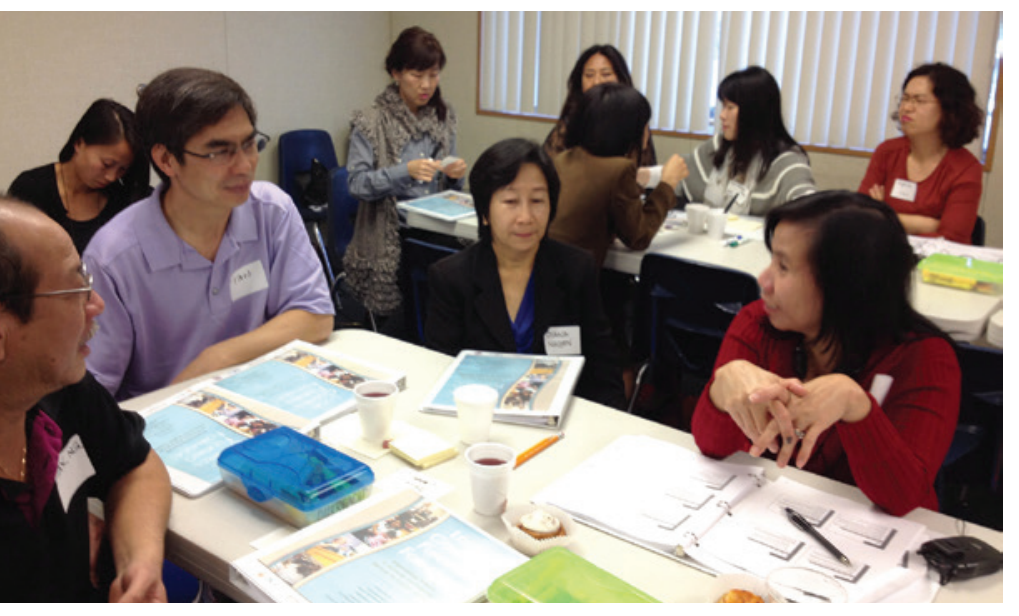

- Include the critical areas (5 priority English Learner Research-Aligned LCAP Rubrics) in this report as part of the technical assistance and review offered to the districts which would require enhancing The LCAP Approval Manual to address these issues.

- Embed the English Learner Roadmap into the System of Support process.

- When assisting districts to identify areas of concern, programs and instruction for ELs, a comprehensive approach should include alignment with the English Learner Roadmap principles and elements focused on assets-based approaches.

- Develop and use tools aligned to the English Learner Roadmap into the System of Support process.

\section{DISTRICT RECOMMENDATIONS}

- Identify and include English Learner cohorts on the LCAP Introductory sections (Areas of Greatest Progress, Greatest Needs, Performance Gaps).

- Allocate resources that respond to the needs of ELOs, RFEPs and other EL cohorts to close opportunity and achievement gaps and respond to identified challenges.

- Identify specific outcomes for the different profiles of ELs with metrics that are sensitive to their language and academic development.

- Complete the LCAP (2017-2020) annual updates based on the revised indicator on the Dashboards' Five by Five Placement Grid for continuous improvement. Use evidence from a self-analysis based on the English Learner Research-Aligned LCAP Rubrics (see Appendix B) to identify areas for improvement.

- Provide professional development for all educators on the implementation of the English Learner Roadmap to build understanding and expertise about the needs of ELs and research-based practices.

- Ensure that professional learning for teachers of ELs addresses integrated and designated ELD as well as differentiation of standards-based instruction.

- Work with district and other bilingual specialists to support the implementation of the new and expanding dual immersion and developmental bilingual programs identified in the LCAPs. 
District Characteristics and Spring 2017 Dashboard English Language Arts (ELA) Academic Indicator English Learners Only (ELO) Results for Sample Districts with an English Learner (EL), ELA Academic Indicator Performance Level Equal to Yellow.

\begin{tabular}{|c|c|c|c|c|c|c|c|c|}
\hline \multicolumn{6}{|c|}{ District Characteristics } & \multicolumn{3}{|c|}{ ELA Academic Indicator for ELO Subgroup } \\
\hline DISTRICT* & $\begin{array}{l}\text { GRADE } \\
\text { SPAN }\end{array}$ & LOCATION & \# OF ELS+ & $\begin{array}{l}\% \text { OF } \\
\text { ELS+ }\end{array}$ & $\begin{array}{l}\text { DEMO } \\
\text { GRAPHICS }\end{array}$ & $\begin{array}{l}\text { PERFORMANCE } \\
\text { LEVEL (COLOR) }\end{array}$ & STATUS & CHANGE \\
\hline$A^{*}$ & $\mathrm{~K}-6$ & City, Large & 11,353 & 60.2 & $\mathrm{HN}, \mathrm{HP}$ & Orange & Very Low & Increased \\
\hline B & P-8 & City, Large & 9,524 & 31.5 & $\mathrm{HN}$ & Red & Very Low & Maintained \\
\hline $\mathrm{C}$ & $\mathrm{K}-8$ & Rural, Distant & 89 & 74.2 & $\mathrm{HP}$ & Red & Very Low & Declined \\
\hline$D^{*}$ & K-Adult & Suburb, Large & 12,692 & 32.8 & $\mathrm{HN}$ & Red & Very Low & Maintained \\
\hline$E^{\star}$ & P-12 & City, Large & 16,439 & 22.4 & $\mathrm{HN}$ & Red & Very Low & Declined \\
\hline $\mathrm{F}$ & $\mathrm{K}-8$ & Suburb, Midsize & 651 & 53.4 & $\mathrm{HP}$ & Red & Very Low & Declined \\
\hline G & $\mathrm{K}-8$ & City, Midsize & 4,159 & 49.2 & $\mathrm{HP}$ & Red & Very Low & Declined \\
\hline $\mathrm{H}$ & P-8 & Town, Remote & 1,627 & 61.8 & $\mathrm{HP}$ & Red & Very Low & Declined \\
\hline$I^{\star}$ & P-Adult & City, Large & 165,453 & 25.9 & $\mathrm{HN}$ & Red & Very Low & Maintained \\
\hline$J^{*}$ & P-Adult & City, Large & 7,694 & 25.3 & $\mathrm{HP}$ & Red & Very Low & Maintained \\
\hline $\mathrm{K}^{*}$ & K-Adult & City, Large & 17,928 & 23 & $\mathrm{HN}$ & Red & Very Low & Declined \\
\hline L & K-Adult & Suburb, Large & 9,114 & 32.2 & $\mathrm{HN}$ & Orange & Very Low & Increased \\
\hline$M^{*}$ & $\mathrm{~K}-8$ & City, Large & 3,092 & 29.1 & $\mathrm{HP}$ & Red & Very Low & Maintained \\
\hline $\mathrm{N}$ & P-8 & Suburb, Large & 3,043 & 51.7 & $\mathrm{HP}$ & Red & Very Low & Declined \\
\hline $\mathrm{O}$ & P-Adult & Suburb, Large & 8,583 & 34.7 & $\mathrm{HN}$ & Red & Very Low & Declined \\
\hline$P^{*}$ & $\mathrm{~K}-8$ & City, Small & 3,883 & 42.7 & $\mathrm{HP}$ & Red & Very Low & Maintained \\
\hline Q & K-Adult & City, Large & 8,600 & 18.4 & $\mathrm{HN}$ & Orange & Very Low & Increased \\
\hline $\mathrm{R}^{\star}$ & K-Adult & City, Midsize & 14,449 & 27.1 & $\mathrm{HN}$ & Orange & Very Low & Increased \\
\hline $\mathrm{S}^{*}$ & P-12 & City, Large & 16,051 & 27.3 & $\mathrm{HN}$ & Red & Very Low & Maintained \\
\hline $\mathrm{T}$ & P-8 & City, Small & 2,174 & 45.8 & $\mathrm{HP}$ & Orange & Very Low & Increased \\
\hline$U^{*}$ & P-8 & City, Large & 3,255 & 67.7 & $\mathrm{HP}$ & Red & Very Low & Declined \\
\hline V & $\mathrm{K}-8$ & City, Small & 10,178 & 61.4 & $\mathrm{HP}, \mathrm{HN}$ & Red & Very Low & Maintained \\
\hline$W^{*}$ & P-Adult & Suburb, Large & 10,652 & 34.4 & $\mathrm{HN}$ & Red & Very Low & Maintained \\
\hline$x$ & $\mathrm{~K}-12$ & Town, Distant & 737 & 54.8 & $\mathrm{HP}$ & Red & Very Low & Declined Sig \\
\hline
\end{tabular}

KEY:

$\mathrm{HN}=$ Districts with an EL population greater than 999

$\mathrm{HP}=$ Districts with an EL percentage greater than $49 \%$.

*Districts were also part of the sampling for the LCAP Year 1 and Year 2 reviews focused on examining increased or improved services for English Learners.

+English Learner Numbers and Percentages for the Spring 2017 Dashboard results were based on 2015-16 reports. 

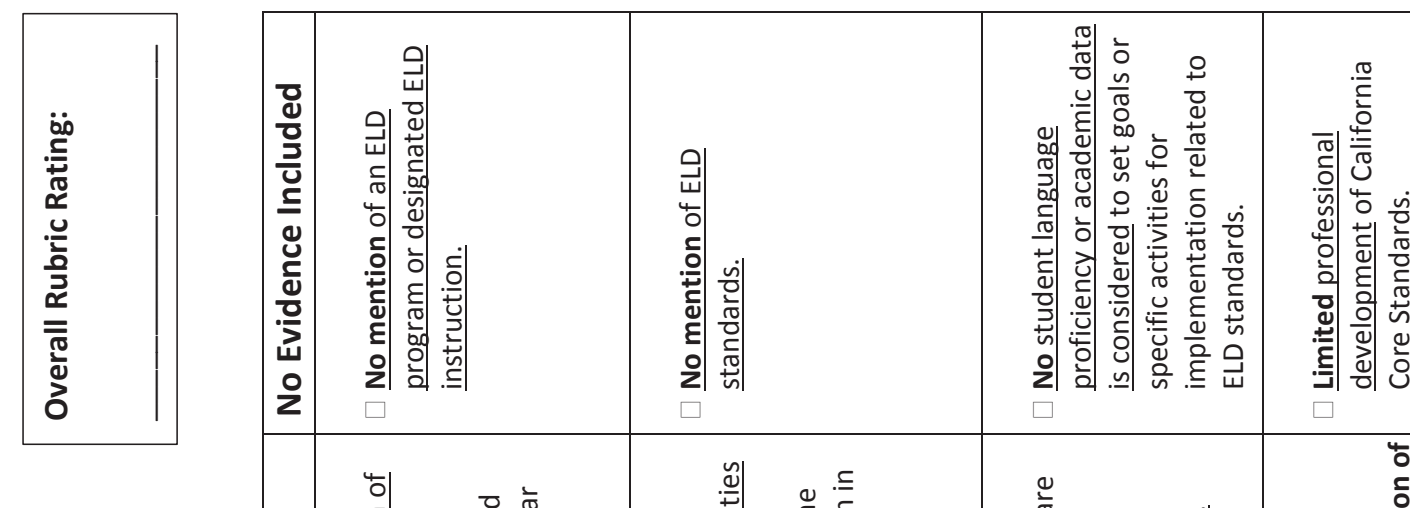

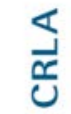

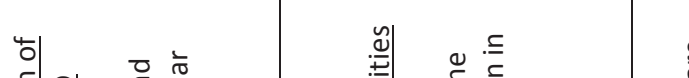
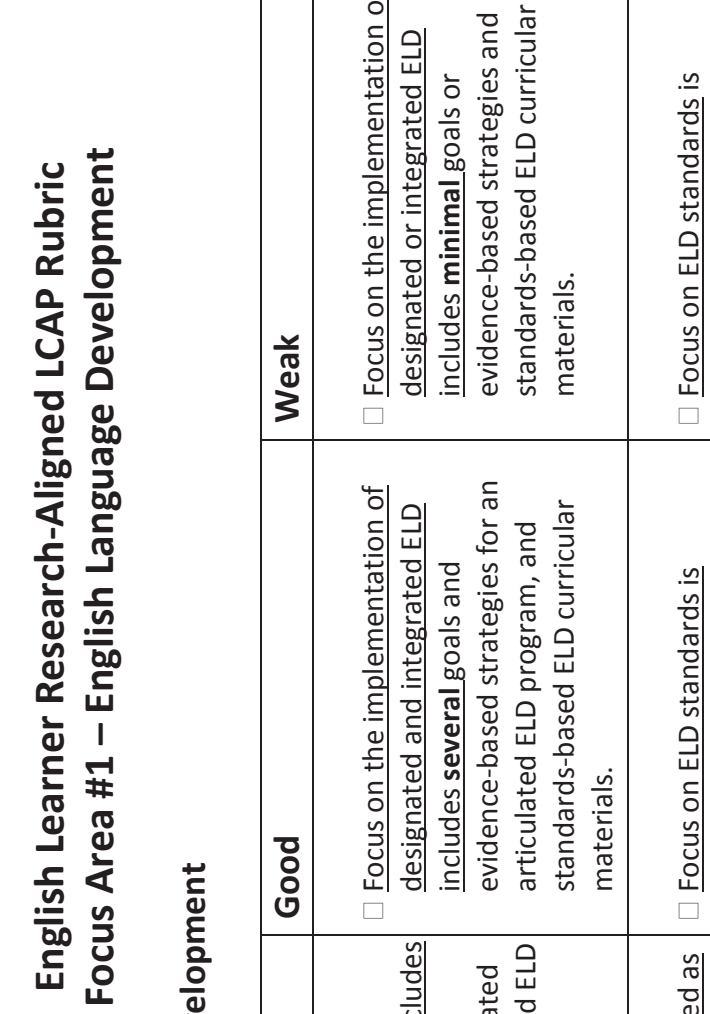

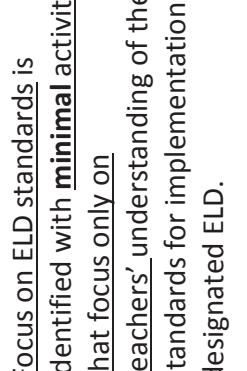

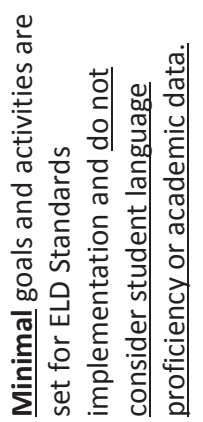
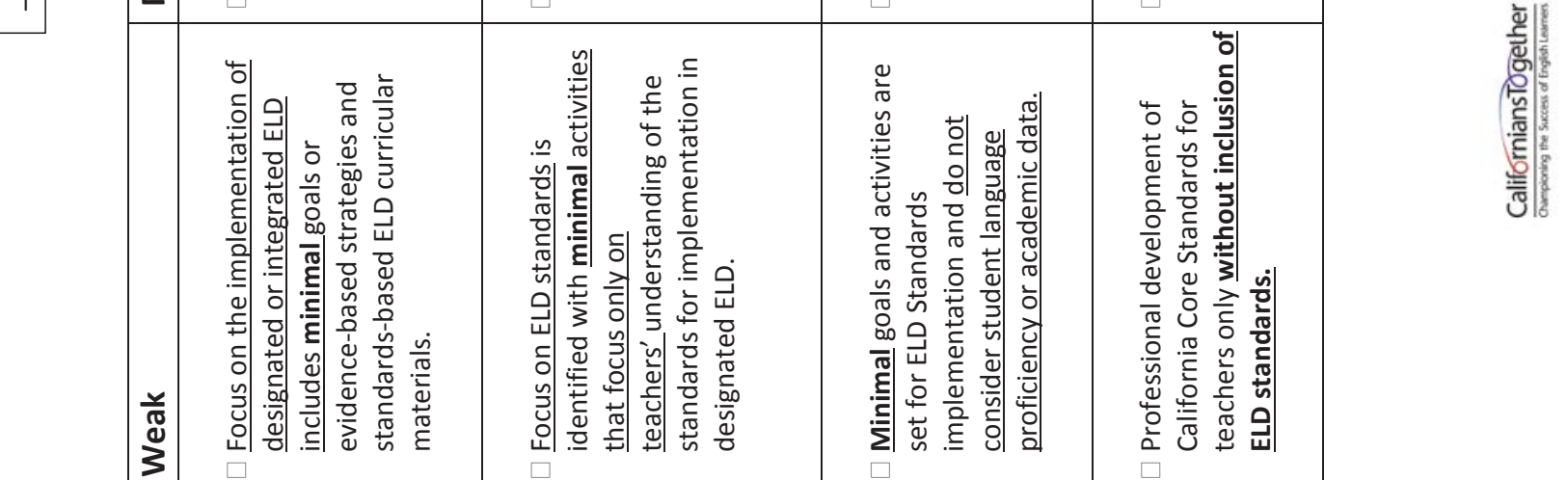

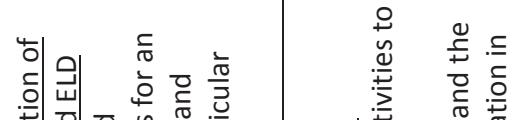

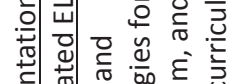

(⿻)丨

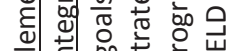

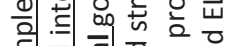

.

ᄃ

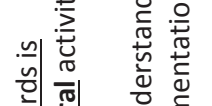

要

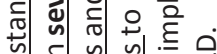

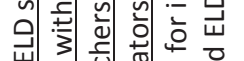

ᄃ)

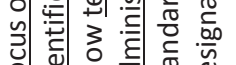

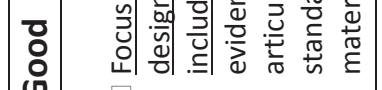

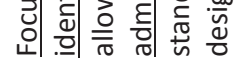

गे 要考

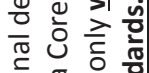

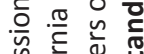

जै

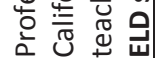

贫

뜬

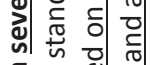

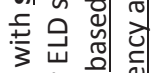

过

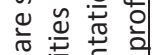

离离至

亲

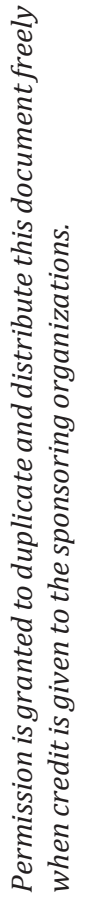

\begin{tabular}{|c|c|c|}
\hline 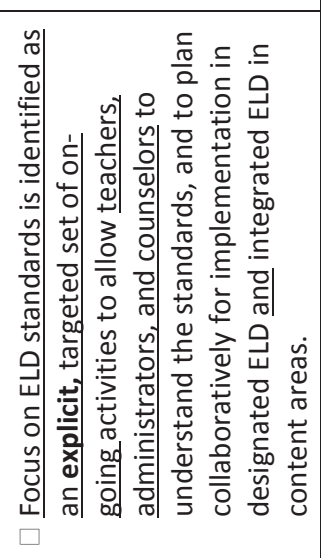 & 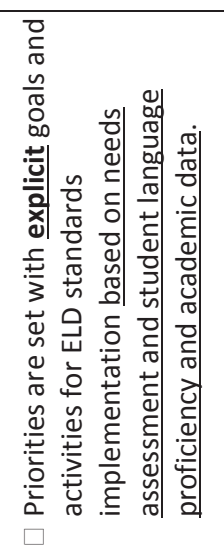 & 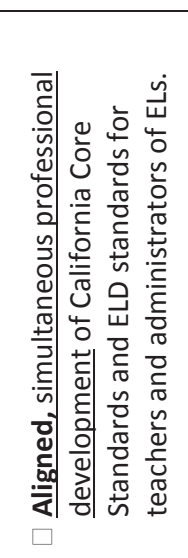 \\
\hline spдерь & 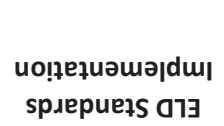 & 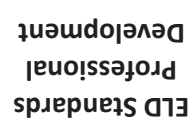 \\
\hline
\end{tabular}




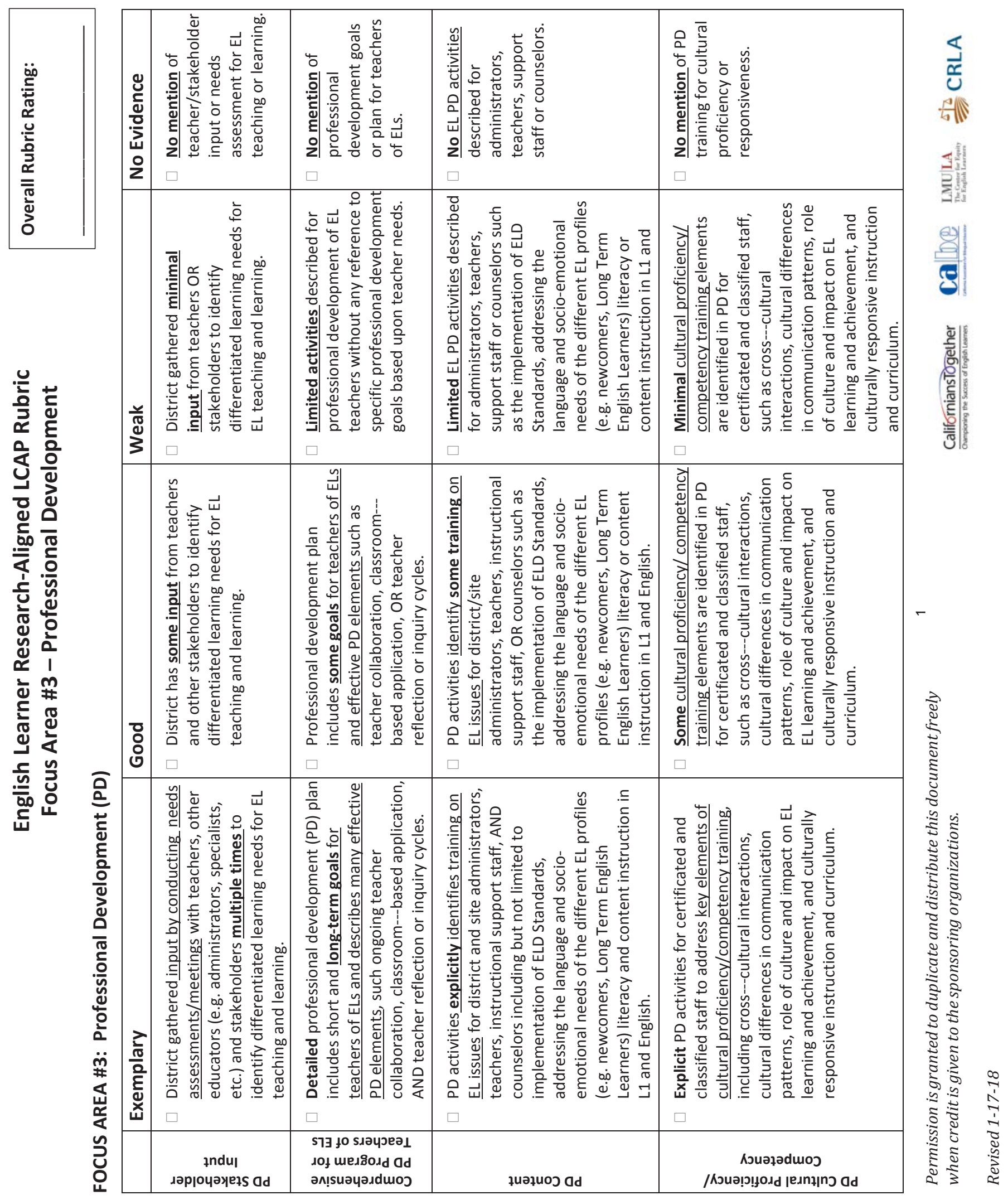




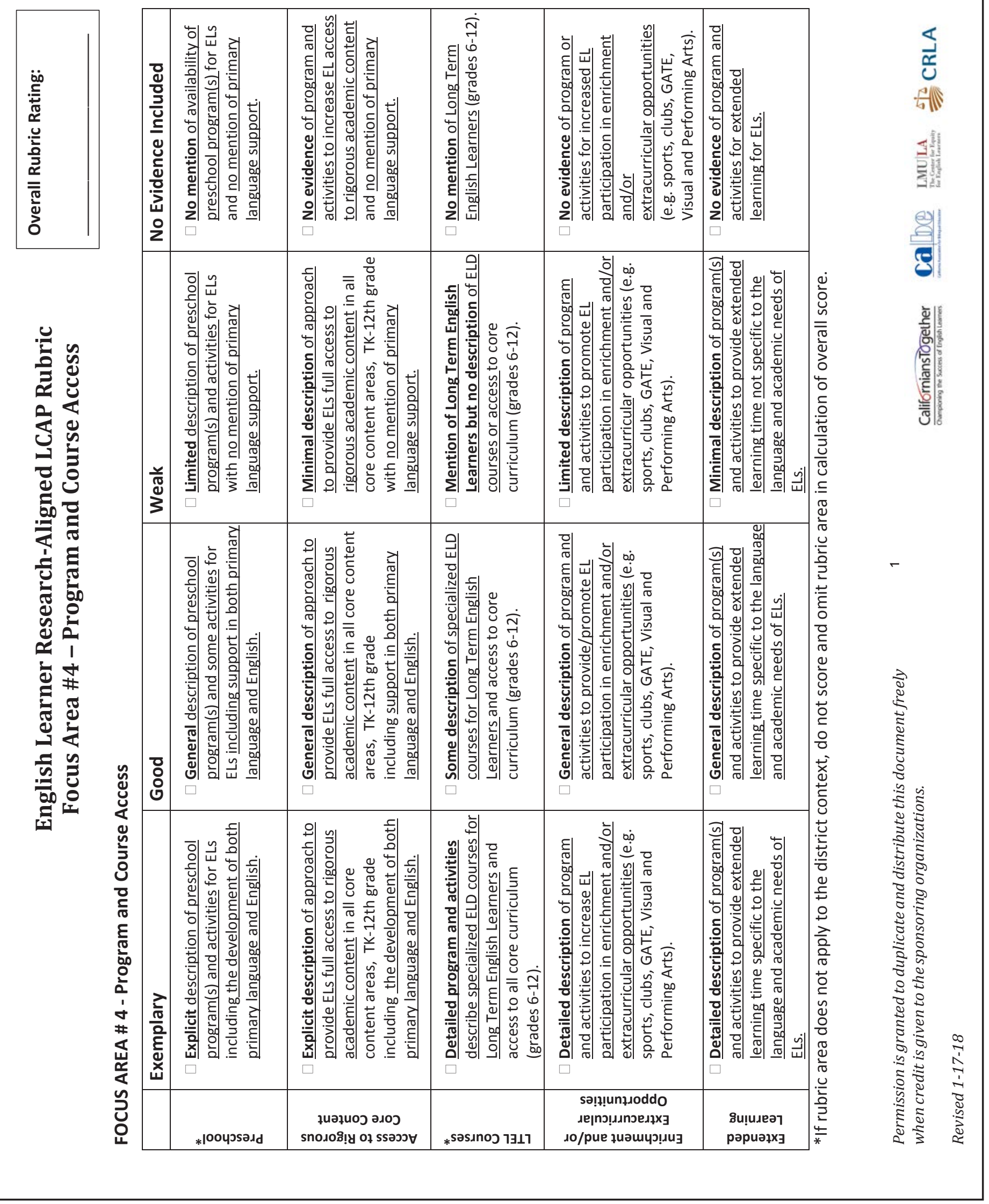




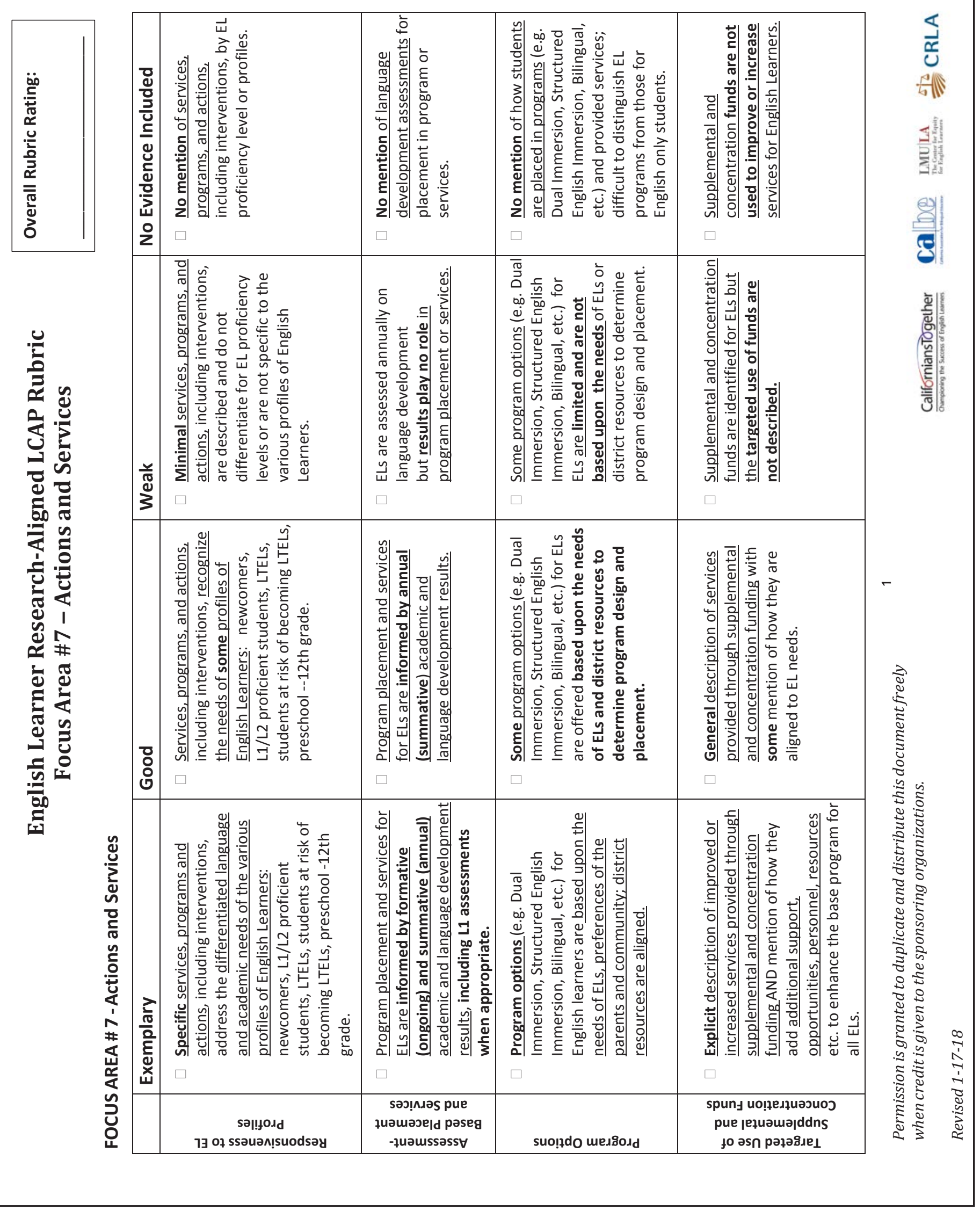




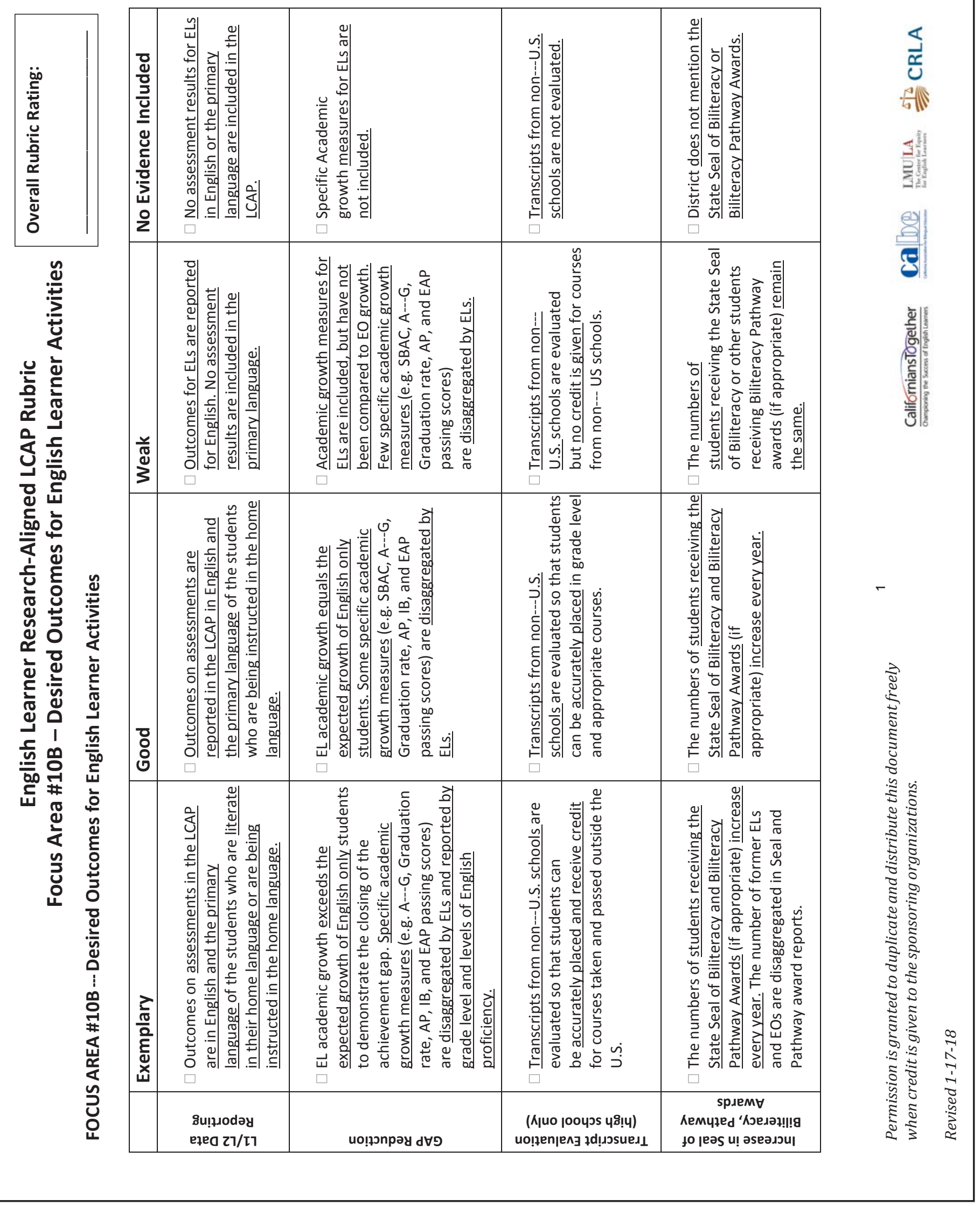




\section{APPENDIX C: LIST OF REVIEWERS}

Thank you to the educators, researchers, and the advocates who participated in the review of the LCAPs.

Lynne Aoki

Californians Together

\section{Elvira Armas}

Center for Equity for English Learners,

Loyola Marymount University

\section{Cassandra Bautista}

Santa Barbara County Education Office

Pye Roberta Cornejo

Alvord Unified School District

Xilonin Cruz-Gonzalez

Californians Together

\section{Laura Díaz}

California Association for Bilingual Education

JunHee Doh

Advancement Project California

Laure Dupre

Fallbrook Union Elementary School District

\section{Zoila Gallegos}

Paramount Unified School District

\section{Martha Hernández}

Californians Together

Sylvia Jáuregui Hodge

Center for Equity for English Learners, Loyola Marymount University

\section{Nancy Hofrock}

Fontana Unified School District

\section{Sherry Kully}

Glendale Unified School District
Magaly Lavadenz

Center for Equity for English Learners,

Loyola Marymount University

\section{Claudia Lockwood}

California Association for Bilingual Education

\section{Erika Menjivar}

Californians Together

\section{Baldwin Moy}

California Rural Legal Assistance

\section{Allyson Osorio}

UnidosUS

\section{Griselda Palma}

San Diego State University

\section{Catherine Retana}

California Rural Legal Assistance

\section{Maxine Sagapolutele}

English Learner Leadership and Legacy Initiative

\section{Shelly Spiegel-Coleman}

Californians Together

Lilia Torres-Cooper

Whittier Union High School District

Maria Valencia

California Association for Bilingual Education

\section{Emma Watson}

Advancement Project California

\section{Leni Wolf}

The Education Trust-West

Mary Helen Ybarra

California Latino School Board Association 
1 Local Control Funding Formula, 2013 (AB 97, SB 91, and SB 97).

2 California Department of Education. (2018). Accountability: California accountability model and school dashboard. Retrieved from https://www.cde.ca.gov/ta/ac/

3 California Department of Education. (2017). Local Control and Accountability Plan and annual update template instructions. Retrieved from https://www.cde.ca.gov/re/lc/ templateinstructions.asp

4 California Department of Education. (2018). English learner roadmap. Retrieved from https://www.cde.ca.gov/sp/el/rm/

5 Armas, E., Lavadenz, M., \& Olsen, L. (2015). Falling short on the promise of increased or improved services for English Learners: A report on year one LCAPs. Long Beach, CA: Californians Together.

Olsen, L., Armas, E., \& Lavadenz, M. (2016). A review of year 2 LCAPs: A weak response to English Learners. Long Beach, CA: Californians Together.

6 Cadiero-Kaplan, K., Lavadenz, M., \& Olsen, L. (2017). Fostering equity and meaningful accountability for California's English Learners (ELs): Utilizing the EL academic indicator as a mechanism to drive continuous improvement and resource allocation. Testimony submitted to the California State Board of Education in March 2017.

7 Fall 2017 Dashboard data was released towards the end of the data analysis process.

8 California Alternate Assessment results are not included in these calculations. Also, to protect the anonymity of students, data is not provided for districts with student groups of less than 11 pupils.

9 California Department of Education. (2018). Spring 2017 dashboard data files and guide. Retrieved from https://www. cde.ca.gov/ta/ac/cm spring2017dashboarddocs.asp

10 Not all LEAs will have an ELO and/or RFEP subgroup with at least 11 students. Therefore, the number of ELO and RFEP subgroups will not match the total number of EL subgroups in the analysis.

11 California Department of Education. (2016). Preparing All Students for College, Career, Life, and leadership in The 21st Century. Retrieved from https://www.cde.ca.gov/ta/ac/ar/ documents/account-report-2016.pdf
12 Californians Together, California Association for Bilingual Education (CABE), California Rural Legal Assistance (CRLA), and the Center for Equity for English Learners. (2015). Does your local control accountability plan (LCAP) deliver on the promise of increased or improved services to English Learners?: 10 research-aligned rubrics to help answer the question and guide your program. Retrieved from https://www.californianstogether. org/product/does-your-local-controlaccountability-plan-lcapdeliver-on-the-promise-of-increased-or-improvedservices-toenglish-learners-10-research-aligned-rubrics-to-help-answerthequestion-and-guide-you/

13 English Learner Progress Indicator (ELPI) is a separate Dashboard Indicator that monitors progress towards English Proficiency, answering only part of the challenge facing English Learners - whether they are moving towards academic proficiency in English while gaining mastery of the language.

14 California Department of Education. (2015). English language arts/English language development framework for California public schools, grades kindergarten through 12. Retrieved from: https://www.mydigitalchalkboard. org/ cognoti/content/file/resources/documents/ac/ ac1376ba/ac1376ba78a91e80241cb0e458caaa57310d0763/ elaeldfmwkfeb17.pdf

15 National Academies of Sciences, Engineering, and Medicine. (2017). Promoting the educational success of children and youth learning English: Promising futures. Washington, D.C.: The National Academies Press. https://doi.org/10.17226/24677

16 California Department of Education. (2018). Global California 2030. Speak. Learn. Lead. Retrieved from: https://www.cde. ca.gov/eo/in/documents/globalca2030report.pdf. 


\section{CaliforniansTogether}

Championing the Success of English Learners

Californians Together is a statewide coalition of parents, teachers, administrators, board members and civil rights non-profit organizations. Our member organizations come together united around the goals of better educating California's 1.3 million English Learners by improving California's schools and promoting equitable educational policy.

This report can be downloaded in pdf format from www.californianstogether.org

For additional paper copies of this report or other information about Californians Together's initiatives contact:

Shelly Spiegel-Coleman, Executive Director

shelly@californianstogether.org

\section{Californians Together}

525 East Seventh Street, Suite 215

Long Beach, CA 90813 562-983-1333

(C) Californians Together, 2018 